\title{
Labor market responsiveness: Assessing seven dimensions of the West Virginia community and technical colleges
}

Ann M. Shipway

West Virginia University

Follow this and additional works at: https://researchrepository.wvu.edu/etd

\section{Recommended Citation}

Shipway, Ann M., "Labor market responsiveness: Assessing seven dimensions of the West Virginia community and technical colleges" (2009). Graduate Theses, Dissertations, and Problem Reports. 4531. https://researchrepository.wvu.edu/etd/4531

This Dissertation is protected by copyright and/or related rights. It has been brought to you by the The Research Repository @ WVU with permission from the rights-holder(s). You are free to use this Dissertation in any way that is permitted by the copyright and related rights legislation that applies to your use. For other uses you must obtain permission from the rights-holder(s) directly, unless additional rights are indicated by a Creative Commons license in the record and/ or on the work itself. This Dissertation has been accepted for inclusion in WVU Graduate Theses, Dissertations, and Problem Reports collection by an authorized administrator of The Research Repository @ WVU.

For more information, please contact researchrepository@mail.wvu.edu. 


\title{
Labor Market Responsiveness: Assessing Seven Dimensions of the West Virginia Community and Technical Colleges
}

\author{
Ann M. Shipway \\ Dissertation submitted to the College of Human Resources and Education \\ at West Virginia University \\ in partial fulfillment of the requirements \\ for the degree of \\ Doctor of Education \\ in \\ Curriculum and Instruction \\ Steven Rinehart, Ed.D., Chair \\ Donald Alexander, Ed.D. \\ Ardeth Deay, Ph.D. \\ Reagan Curtis, Ph.D. \\ Ernest Goeres, Ph.D. \\ Perry Phillips, Ed.D. \\ Department of \\ Curriculum and Instruction - Literacy Studies \\ Morgantown, West Virginia \\ 2009
}

Keywords: Community College, Labor Market, Workforce Development

Copyright 2009 Ann M. Shipway 


\title{
ABSTRACT \\ Labor Market Responsiveness: Assessing Seven Dimensions of the West Virginia Community and Technical Colleges
}

\begin{abstract}
Ann M. Shipway
The purpose of this study was to determine the extent to which the presidents of the ten public community and technical colleges in the state of West Virginia perceive their institutions implementing the seven dimensions of college life in support of labor market responsiveness identified by the U.S. Department of Education.
\end{abstract}

The U.S. Department of Education studied labor market responsiveness at 30 community colleges nationwide. They identified seven characteristics of college life shared among labor market responsive community colleges which include 1) leadership and governance; 2) organizational structure and staffing; 3) organizational culture; 4) resources and funding; 5) information and data; 6) relationship building; and 7) partnerships.

This study attempted to determine whether the institutional factors of size, student FTE, number of counties in the institutional service area, and the annual state allocated budget were related to the presidents' perceptions regarding the seven dimensions, and to determine if there was a relationship between the presidents' demographics and the seven dimensions.

The ten presidents of each West Virginia public community and technical college completed an on-line survey resulting in a 100\% response rate. The data were analyzed using descriptive statistics, Cronbach's alpha coefficient, Spearman correlation coefficient, and Cohen's $d$.

Data indicated that there were measurable relationships between the seven dimensions and the variables of institutional size, number of counties in the service area, and the institutions' annual state allocated budget. There were measurable relationships regarding the demographics of the presidents and the seven dimensions. Implications of this study may include institutions' emphasis on the following 1) alternative funding; 2) professional development regarding the seven dimensions; 3) recognition and rewards; 4) building positive partnerships; 5) improved access to and use of information and data.

Recommendations for further research included other populations distinct from the presidents such as faculty and staff, larger populations, and a mixed methods approach including interviews. 


\section{Acknowledgements}

First, I'd like to acknowledge and express my appreciation to my family. They have been supportive and understanding during my educational journey.

I'd also like to thank my committee members: Dr. Donald Alexander, Dr. Reagan Curtis, Dr. Ernest Goeres, and Dr. Perry Phillips, and Dr. Steven Rinehart. Their questions and insights challenged me to become a better scholar. I wish to especially thank Dr. Peter Checkovich, who was generous in sharing his experience and knowledge of West Virginia community colleges with me throughout this academic journey.

I also want to acknowledge and thank Dr. Ardeth Deay, who guided my research and continued to support and motivate me through this process.

Finally, I dedicate my research to my parents, Bruce and Mary Ann Eckard, who were my first teachers and who showed me that education opens doors to freedom. 


\section{TABLE OF CONTENTS}

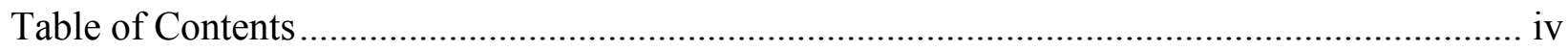

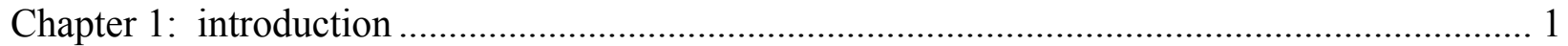

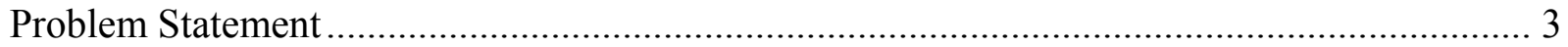

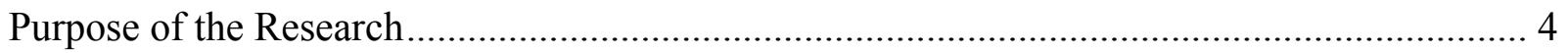

Research Questions .................................................................................................. 4

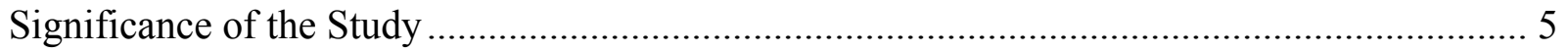

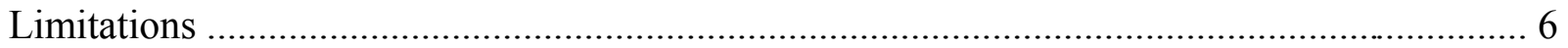

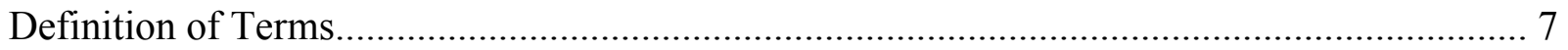

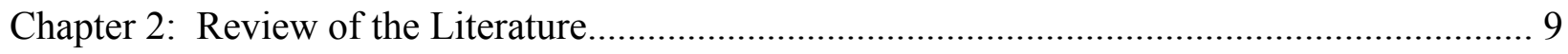

History of Community Colleges ............................................................................. 9

History of Community and Technical Colleges in West Virginia ........................................ 11

Workforce Development in Community Colleges ............................................................... 14

Development of the Seven Dimensions of College Life ................................................. 15

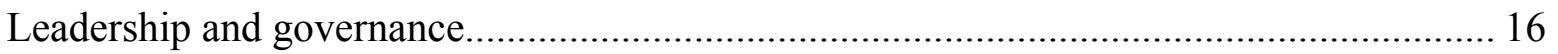

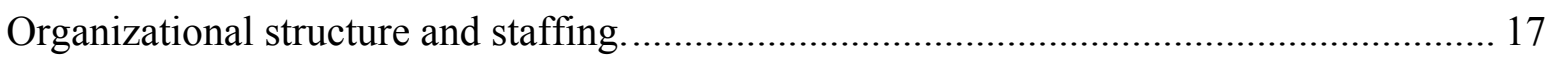

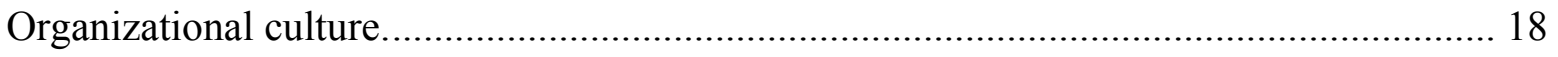

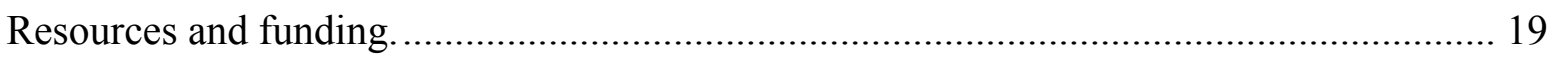

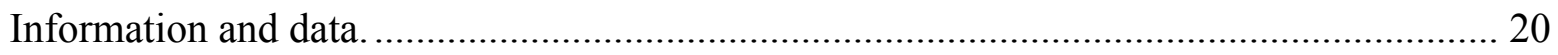

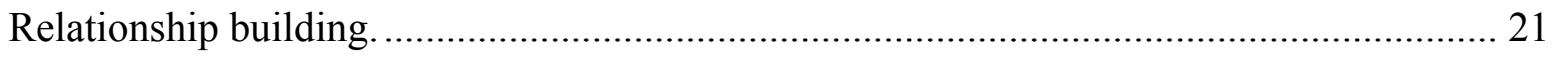

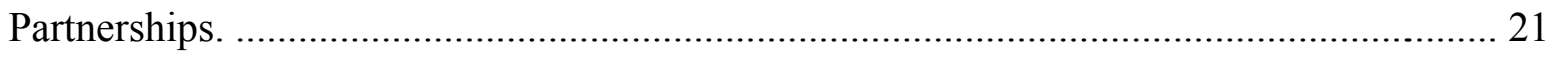

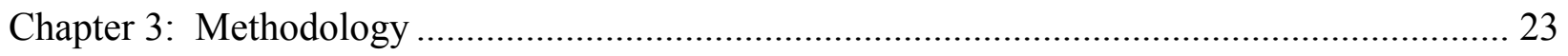

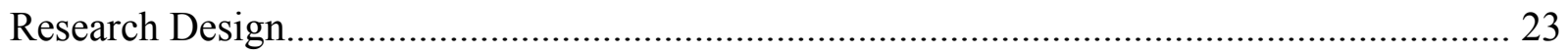

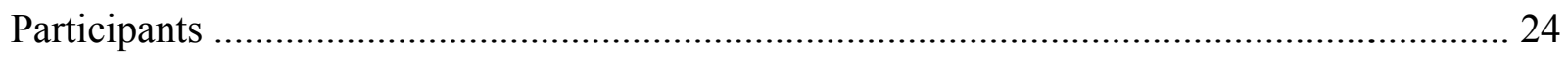

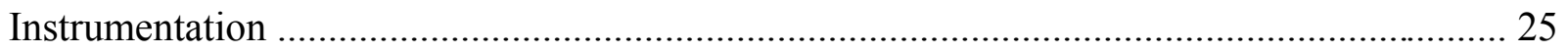

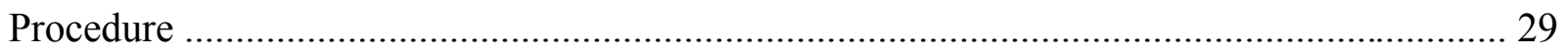

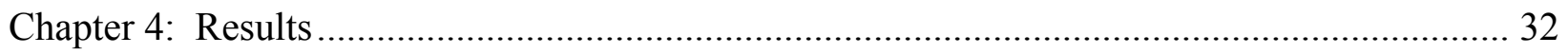

Demographics of Community and Technical Colleges ..................................................... 26

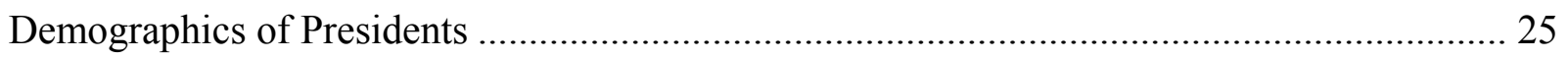

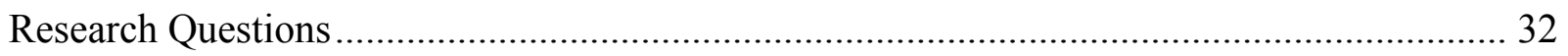

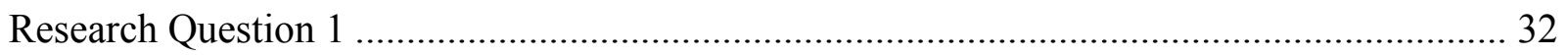

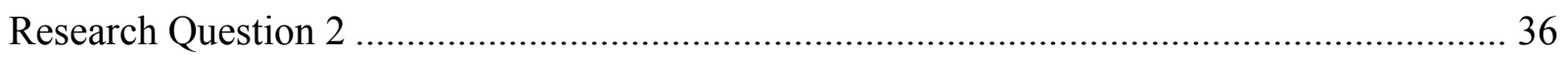

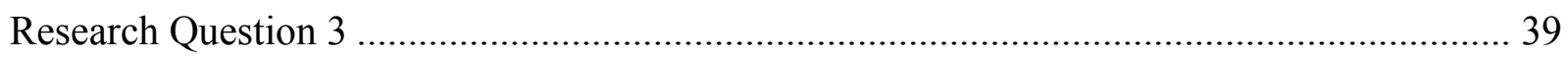




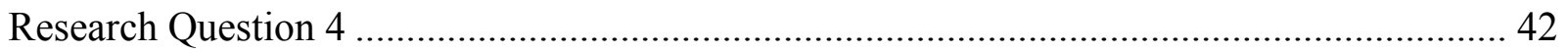

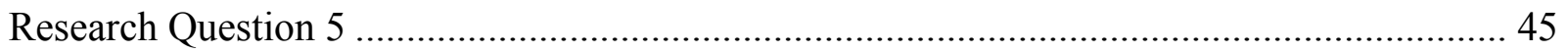

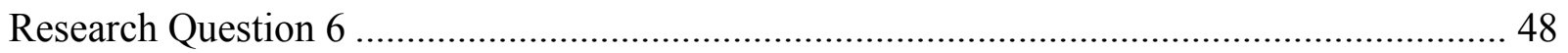

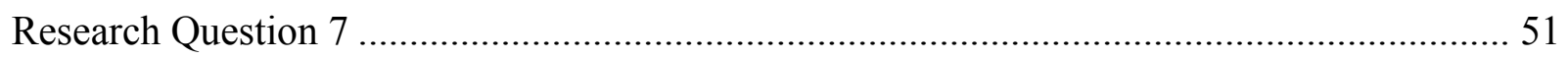

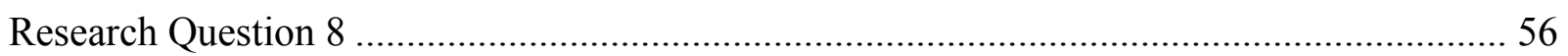

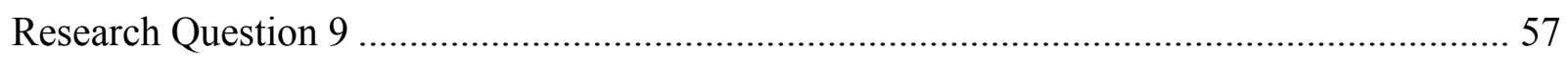

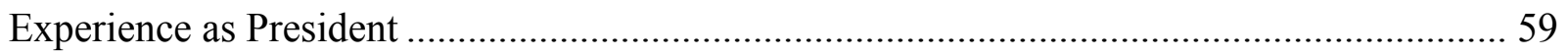

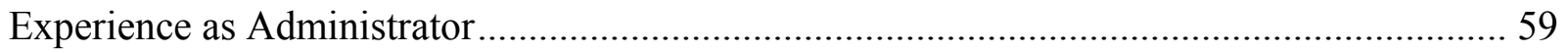

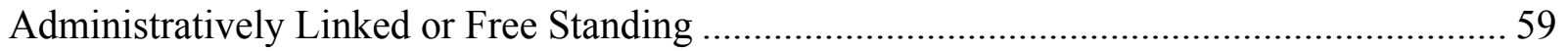

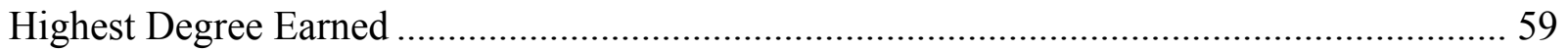

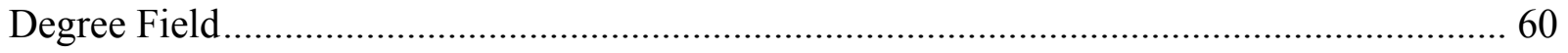

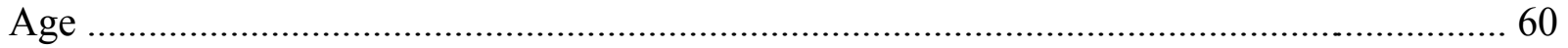

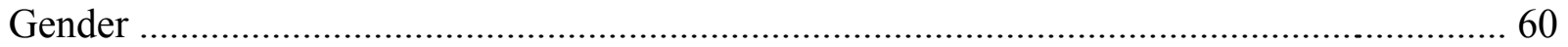

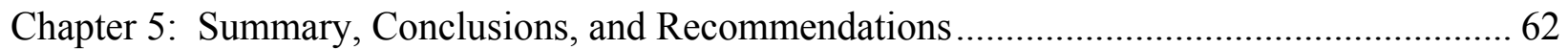

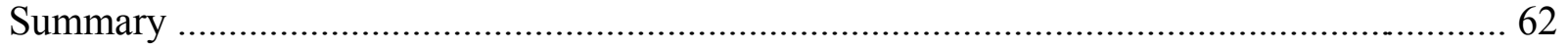

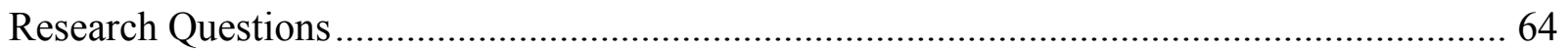

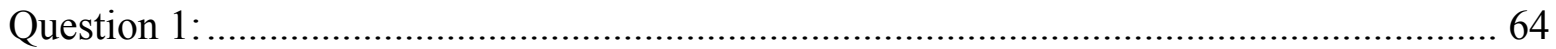

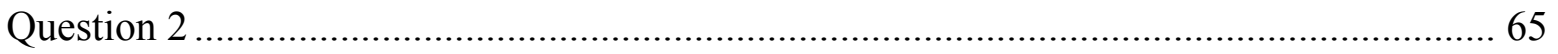

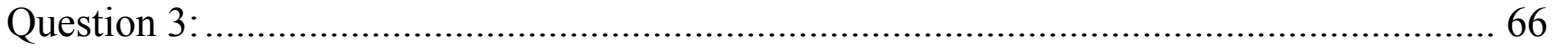

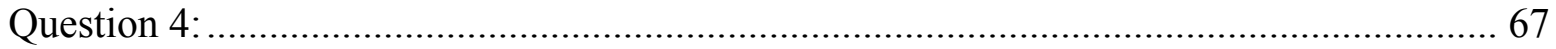

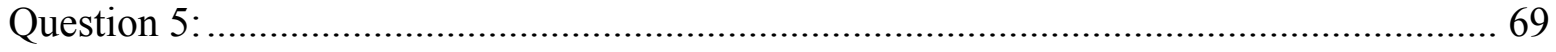

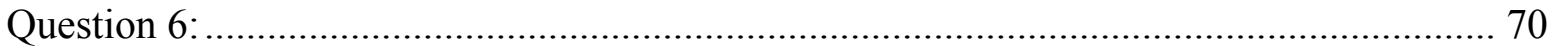

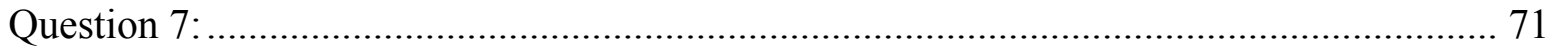

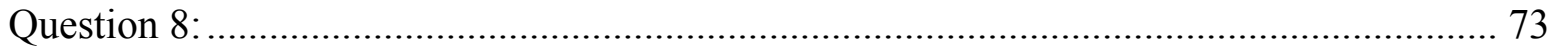

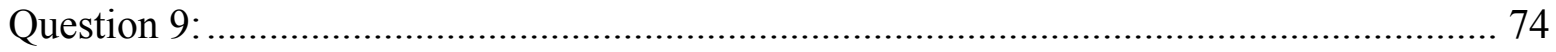

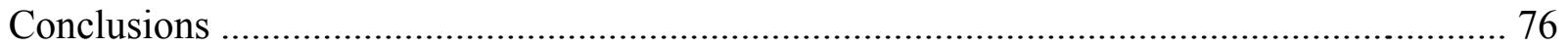

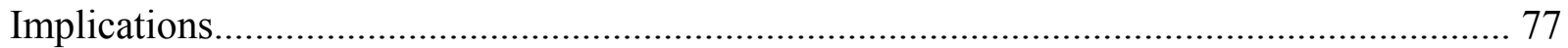

Recommendations for Further Research..................................................................... 79

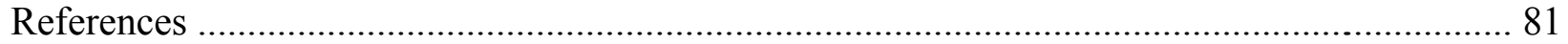

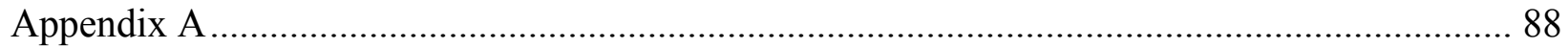

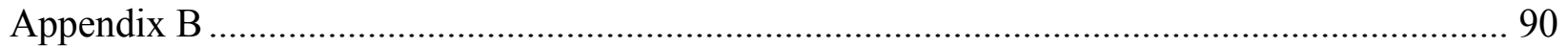

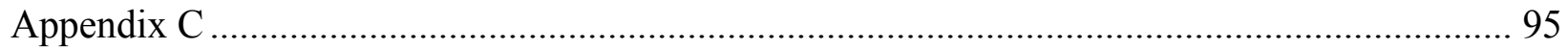

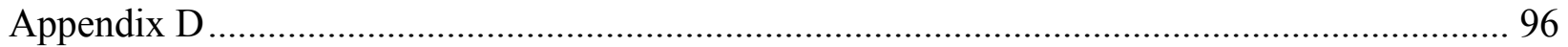




\section{Tables and Figures}

Table 3-1 Gender and Age Range of Presidents .......................................................................25

Table 3-2 Community and Technical College 2007 Demographics ..........................................27

Table 4-1 Leadership and Governance Frequencies ..............................................................34

Table 4-2 Leadership and Governance Descriptive Statistics .................................................35

Table 4-3 Organizational Structure and Staffing Frequencies .................................................37

Table 4-4 Organizational Structure and Staffing Descriptive Statistics ................................... 38

Table 4-5 Organizational Culture Frequencies .........................................................................40

Table 4-6 Organizational Culture Descriptive Statistics........................................................... 41

Table 4-7 Resources and Funding Frequencies .................................................................. 43

Table 4-8 Resources and Funding Descriptive Statistics ..................................................... 44

Table 4-9 Information and Data Frequencies ....................................................................... 46

Table 4-10 Information and Data Descriptive Statistics ....................................................... 47

Table 4-11 Relationship Building Frequencies ................................................................... 49

Table 4-12 Relationship Building Descriptive Statistics ......................................................... 50

Table 4-13 Partnership Frequencies ........................................................................................ 52

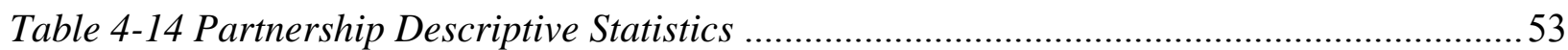

Table 4-15 Scale Reliability and Descriptive Statistics ..........................................................54

Figure 4-16 Comparison of President's Responses.............................................................. 55

Table 4-17 Relationship between Perceptions and Demographics ..........................................56

Table 4-18 Seven Characteristics and Participant Demographics .......................................... 58 


\section{CHAPTER 1: INTRODUCTION}

As global competition continues to pressure business and industry to be more productive, America's community colleges are emerging as premier providers of workforce education. The need for $21^{\text {st }}$ century community colleges to become flexible, market responsive providers of postsecondary education, worker retraining and certification, and continuing education stems from a workplace that demands rapidly changing job skills (MacAllum, Yoder, \& Poliakoff, 2004).

The mission of community colleges has evolved beyond their traditional roles of open access, vocational education and as an entrée into 4-year colleges, to include mid- and high-level workforce training (Harmon \& MacAllum, 2003). Labor market responsive community colleges provide training and educational opportunities for learners.

At their best, community colleges work closely with business and industry to provide workforce education to students whose journeys and goals vary. These students range from those without workforce experience to veteran employees upgrading their skills to advance in their jobs or make career transitions.

For community college leaders, the connection between the college and workforce development is obvious (Nespoli, Lam, \& Farbman, 2004). Responsive community colleges enable displaced workers to transition from one career to another, employed workers to learn new skills, and students to prepare for meaningful careers (MacAllum et al. 2004). When companies are deciding where to locate or relocate, they want to know that they can depend on finding well-trained technical workers in the local community. A well-prepared workforce attracts business and industry, high-paying jobs, and the promise of future growth for the community. 
In 2004, the U.S. Department of Education, Office of Vocational and Adult Education, sponsored the Community College Labor Market Responsiveness (CCLMR) Initiative. This initiative was undertaken in partnership with Westat and the Academy for Educational Development. The purpose of the Community College Labor Market Responsiveness Initiative was to provide information that would assist community colleges in keeping pace with the needs of a diverse student population and a dynamic labor market. MacAllum et al. (2004) describe the main goals of this initiative as follows:

1) Determine the characteristics of a "market responsive" community college and identify the indicators and measures by which market responsiveness can be judged; (2) identify the policies and practices community colleges have put in place to facilitate and support labor market responsiveness; 3) pinpoint the steps colleges can take to improve labor market responsiveness and the quality of customized programs they offer to students; and 4) disseminate that knowledge to the field. (p. 1)

The U.S. Department of Education studied labor market responsiveness at 30 community colleges nationwide. They identified seven common characteristics shared among these community colleges. These seven characteristics or dimensions of college life support labor market responsiveness. The study's authors defined a labor market responsive college as one that:

Delivers programs and services that align with and seek to anticipate the changing dynamics of the labor market its serves. These programs and services address the educational and workforce development needs of both employers and students as part of the college's overall contribution to the social and economic vitality of its community. (U.S. Department of Education, 2004, p. 5) 


\section{Problem Statement}

One of the main goals of the Community College Labor Market Responsiveness Initiative was to determine the characteristics of a market responsive community college and identify the indicators and measures by which "market responsiveness" can be judged (MacAllum et al. 2004). As a result, the U.S. Department of Education, Office of Vocational and Adult Education, identified seven dimensions of college life that are shared by market responsive community colleges. These seven dimensions are (a) leadership and governance, (b) organizational structure and staffing, (c) organizational culture, (d) resources and funding, (e) information and data, (f) relationship building, and (g) partnerships.

Community colleges are unique in higher education. Throughout their history, community colleges have linked student goals of productive employment and careers to the economic and workforce development goals of having workers with the knowledge and skills to build and sustain flourishing economies. Community college leaders must continue to serve the needs of their service areas or service regions. Although the definition of what it means for a community college to serve its community has changed over the years, the community college sees its mission as primarily one of providing education to its local community, including educating people to survive and thrive in a global economy (Vaughan, 2006).

The linkage between community colleges and their local labor markets is at the heart of the community college mission. Labor market responsive community colleges actively consider the local and national economic environment and deliver training and educational programs that address labor market needs and support economic competitiveness in a changing global economy. 


\section{Purpose of the Research}

The purpose of this research is to determine to what extent the presidents of the ten public community and technical colleges within the state of West Virginia perceive their institutions as implementing the seven dimensions of college life in support of labor market responsiveness.

Questions arise related to the support of labor market responsiveness. Are there specified institutional factors of the community and technical colleges that relate to the support of labor market responsiveness? Is there a relationship between the demographics of the West Virginia public community and technical college presidents and the seven dimensions of college life that support labor market responsiveness?

\section{Research Questions}

In order to determine the degree to which the presidents of the ten public community and technical colleges within the state of West Virginia perceive their institutions as able to implement the seven dimensions of college life in support of labor market responsiveness, the following questions guide this study:

1. What is the extent to which West Virginia's public community and technical college presidents perceive their institutions as exhibiting leadership and governance?

2. What is the extent to which West Virginia's public community and technical college presidents perceive their institutions as having appropriate organizational structure and staffing?

3. What is the extent to which West Virginia's public community and technical college presidents perceive their institutions as exhibiting supportive organizational culture?

4. What is the extent to which West Virginia's public community and technical college presidents perceive their institution's allocation of resources and funding to be sufficient? 
5. What is the extent to which West Virginia's public community and technical college presidents perceive their institutions as utilizing information and data?

6. What is the extent to which West Virginia's public community and technical college presidents perceive their institutions as building relationships with their relevant constituencies?

7. What is the extent to which West Virginia's public community and technical college presidents perceive their institutions as establishing partnerships with local employers and economic development agencies?

8. Is there a relationship between the extent to which the presidents perceive their institutions as implementing the seven dimensions of college life supporting labor market responsiveness and the institutional factors of (a) size of institution based on student FTE, (b) number of counties in the service area, and (c) annual operating budget?

9. Is there a relationship between the extent to which the presidents perceive their institutions as implementing the seven dimensions of labor market responsiveness and the presidents' demographics?

\section{Significance of the Study}

The American economy continues to experience change. Intensified global competition and technological developments increase the need for workers with flexible and technical skills. The American worker needs to demonstrate a high degree of specialized knowledge and the ability to adapt to changing workplace environments. Community colleges are cognizant of the need to develop partnerships with local businesses and economic development agencies to 
address the challenges of changing local economies. Community colleges realize that global, national, and regional economies influence the local economy within a college's service area.

Community colleges connect to local employers to understand what skills and competencies they are looking for and to develop strong workforce development programs within the context of their curricula and their educational opportunities. Now more than ever, it is vital that all community colleges realize their potential to strengthen the U.S. economy by meeting the workforce development needs of its citizens and employers (MacAllum et al. 2004).

This study may provide community college presidents and leaders with a framework to assess their institution's position on each of the seven dimensions of college life that supports labor market responsiveness. It may also support the efforts of community college presidents and leaders by providing information that can be used to create benchmarks for strengthening specific aspects of performance. In addition, the information obtained from this study could be utilized in the development of an institutional strategic plan.

\section{Limitations}

The public community and technical colleges of West Virginia may not be typical of other community colleges in other regions of the country. As a result, the reader should be careful not to transfer these results to institutions outside the region of this study. This study is limited to ten participants. The ten participants represent all of the public community and technical colleges in West Virginia. The small sample limits applicability of inferential statistics. The correlational nature of the data is survey based, and there is no attempt to address the causes of the relationships shown in the study.

The survey of each community and technical college site relies upon one respondent's assessment and ratings of the college's ability to support labor market responsiveness. The data 
are only as good as the respondents' ability and willingness to provide accurate and realistic answers.

This study utilizes the 2007 annual operating budget for each of the ten public community and technical colleges in West Virginia. This data is found in the 2007 Higher Education Report Card. This budget data is a state allocation and does not include an institution's total revenue. Therefore, is not representative of an institution's total annual budget or per student expenditure.

\section{Definition of Terms}

Community and Technical College - The West Virginia public two-year institution that is accredited to award the Associate in Arts, the Associate in Sciences, or the Associate in Applied Sciences as its highest degree.

Economic Development - "Economic development has traditionally been defined as the process by which individuals or organizations are motivated to invest capital in a community, generating or expanding industrial, commercial, or service activities, and thereby, increasing or retaining jobs" (Parnell, 1990, p. 58).

FTE - FTE is defined as full time equivalent. The student FTE or full time equivalent student credit load will be used for the purpose of this study.

Labor Market Responsive College- A community college that “delivers programs and services that align with and seek to anticipate the changing dynamics of the labor market it serves. These programs and services address the educational and workforce development needs of both employers and students as part of the college's overall contribution to the social and economic vitality of its community" (MacAllum et al. 2004, p.7). 
President - The administrative head or chief executive officer of the community and technical college.

Workforce Development - Programs in the community college that include but are not limited to customized training for business and industry, research services, small business incubation and assistance, performance-based contracted employment and training programs (Katsinas \& Lacey, 1989).

In light of the importance of labor market responsiveness, this study attempts to discover the extent to which this responsiveness exists in the ten public community and technical colleges within West Virginia and those factors which support its presence. Chapter 2 presents a review of the literature that is pertinent to the study. Chapter 3 provides a description of methodology and statistical procedures to be used in this study. This chapter presents the survey instruments, identifies the process for data collection, and outlines statistical methods used for analyzing the data. Chapter 4 presents and discusses the findings and results of the research questions raised in Chapter 1. The final chapter, Chapter 5, presents the summary, conclusions, and recommendations for future study. 


\section{CHAPTER 2: REVIEW OF THE LITERATURE}

This chapter covers four main sections. The first section is an overview of the history of community colleges. The second section provides a summary of the history and development of the community and technical colleges in West Virginia. The third section presents literature that describes the importance of workforce development and labor market responsiveness in community colleges. The fourth section is an overview of the literature relevant to this study and an overview of the literature used by the U.S. Department of Education, Office of Vocational and Adult Education, to develop and document the seven dimensions of college life that support labor market responsiveness.

\section{History of Community Colleges}

In more than 100 years of existence, the American community college has provided educational opportunities for millions of people. The literature regarding the history of American community colleges begins with the Morrill Act in 1862. Often referred to as the Land Grant Act, the Morrill Act expanded access to public higher education, introduced new types of courses, and attracted students previously excluded from higher education (Vaughan, 2006). As a result of the Morrill Act, the new public institutions composed the first national workforce development initiatives.

Industries emerged during the $20^{\text {th }}$ century and the pressure to train workers, coupled with the developments of science and technology, gave momentum to the efforts to establish two-year colleges that combined liberal education with college-level vocational instruction. Cohen and Brawer's The American Community College (third edition, 1996), defines the functions and historical evolution of community colleges from their start as junior colleges in 
1901 in Joliet, Illinois to their current position on the U.S. higher education landscape. Joliet Junior College began as an extension of a local high school. This was the nation's first major facility constructed specifically for use by a public junior college (Vaughan, 2006). This junior college is considered the oldest continuously operating public two-year college in the United States.

Another milestone in the history of community colleges was the establishment of the American Association of Junior Colleges in 1921. This organization was later renamed the American Association of Community and Junior Colleges. In 1992 the name was changed again to the American Association of Community Colleges, with the understanding that junior, technical, private, and proprietary two-year institutions could all fit within the term community college (Phillippe \& Sullivan, 2005).

Other significant moments in the life of American community colleges include the Truman Commission in 1947 which sought to create a national network of community colleges. The original intent of this community college initiative was to focus on the purpose of providing the first two years of a four-year education. President Truman's Commission on Higher Education encouraged the colleges to "attempt to meet the total post-high school needs of the community" and community colleges have broadened their mission since (Bogart, 1994). After World War II, community colleges enjoyed considerable growth. Enrollment in community colleges swelled during the 1960s. According to Cohen and Brawer (2003) more than 450 new colleges opened their doors, and a major facilities construction boom occurred as a result of a strong economy. Coley (2000) explains that this tremendous expansion was fueled by the push for universal education, the GI Bill, the baby boom, the civil rights movement, the nation's needs 
for worker training, and a robust national economy. Today there are approximately 1,300 community colleges in the United States (American Association of Community Colleges, 2004).

The concept of a comprehensive community college was defined in the 1960s as colleges were called on to provide a broad range of programs including transfer education, vocational training, noncredit courses, customized training for business and industry, and cultural enrichment opportunities. Growth and change have become standard for community colleges. The number of institutions has increased throughout the United States, and their enrollments have grown.

Today most Americans have access to a community college within an hour's drive of their homes or workplace. They can turn to their local community college whenever they have learning needs. The American Association of Community Colleges has estimated that nearly half of all people beginning a college career start out in one of America's community colleges (American Association of Community Colleges, 2004). Throughout the literature of the history of community colleges, these institutions of higher education are recognized as a significant element of the economic well-being of the communities and states they serve. Today, every state has one or more public community college (Vaughan, 2006).

\section{History of Community and Technical Colleges in West Virginia}

According to the literature, community and technical colleges developed early in the history of West Virginia. A report, the Plan for Comprehensive Community College Education in West Virginia, that was commissioned by the Board of Regents in response to House Concurrent Resolution No. 16 (West Virginia Board of Regents, 1971) called for the development of community colleges as discrete elements of baccalaureate institutions. According to this report, West Virginia University established a branch campus in 1895 in 
Montgomery, West Virginia, which later evolved into the West Virginia Institute of Technology. In 1901 West Virginia University established a branch campus at Potomac State in Keyser, West Virginia. Most programs at these branch campuses were limited to college transfer courses.

In 1961, the State Legislature passed legislation which allowed the establishment of twoyear branch colleges which would offer liberal arts, terminal education, and adult education (Plan for Comprehensive Community College Education in West Virginia, 1971). As a result, West Virginia University opened a branch at Parkersburg. Marshall University opened branches in Williamson and Logan. West Liberty opened a branch in Hancock County. The major role of these branch campuses was to provide transfer coursework and to focus efforts on providing the first two years of a four-year degree program.

In 1966 the West Virginia Committee on Higher Education conducted a study which states that occupational curricula were imperative (Higher Education in West Virginia - A Self Assessment, 1966). A second study, a Southern Regional Education Board report to the West Virginia Board of Regents, found that the existing two-year offerings were limited in scope, lacked in enrollment, and were inefficiently distributed throughout the State. This report recommended that the State establish a comprehensive community college system (Assessment of Two-Year College Needs in West Virginia, 1970).

The Sixtieth Session of the West Virginia Legislature enacted two measures created to support the development of a comprehensive community college system (Plan for Comprehensive Community College Education in West Virginia, 1971.) First, House Concurrent Resolution No. 16 charged the Board of Regents to design and recommend a plan for establishing, operating, and maintaining a comprehensive community college system. Second, Senate Bill 255 authorized the Board of Regents to separate from their parent four-year 
institutions and convert them to community colleges (Plan for a Comprehensive Community College System in West Virginia, 1971).

Another significant report in the development of a community college system is the 1989 study, Building for a New Century: Higher Education in West Virginia. This study was contracted by the Sarah and Pauline Maier Foundation and was conducted by the Carnegie Foundation for the Advancement of Teaching. One of the priorities outlined in this report was "to build a network of community colleges to increase higher education access and stimulate economic renewal in every section of the state" (Building for a New Century: Higher Education in West Virginia, 1989, p. 5). The study concluded that the state's community and technical college system needed to be restructured, and it recommended that all community and technical colleges become freestanding institutions.

During the 1992 legislative session, Senate Concurrent Resolution 30 was passed which created the Higher Education Advocacy Team (HEAT). A committee for Education and Workforce Preparation to Meet the Current and Future Needs of West Virginia was formed as an outcome of HEAT (Report of the Higher Education Advocacy Team, 1992). As a result of this committee's findings, the State adopted statutory goals for post-secondary education in 1993. Senate Bill 547 was then developed to restructure the state's system of higher education to meet these statutory goals. This Senate Bill proposed that community and technical colleges operate as independently as possible.

The West Virginia Legislature passed Senate Bill 653 in 2000. This Senate Bill created ten public community and technical colleges within the State. Until this legislation was passed, West Virginia had three freestanding community and technical colleges not attached to a fouryear institution. The most significant change that this legislation brought was that those 
institutions that were linked to a four-year institution, also known as a component college, must earn independent accreditation.

Later in 2004, the West Virginia Legislature passed Senate Bill 448. This created conditions for component community and technical colleges to become as independent as possible. Community and technical colleges that were linked to four-year institutions now had the authority to develop fiscal, administrative, and programmatic autonomy. All previous provosts were named as presidents. Senate Bill 448 also named consortia planning districts for each of the ten community and technical colleges. Appendix A shows the ten public community and technical colleges within West Virginia and their consortia planning districts.

In summary, the literature regarding the history of community and technical colleges in West Virginia describes a slow evolution from the establishment of two branch campuses to the ten community and technical colleges operating today. During this evolution, the community and technical colleges have focused their mission primarily on providing access to higher education to West Virginia citizens and on developing the workforce skills of these citizens in order to compete in a global economy.

\section{Workforce Development in Community Colleges}

Over the course of their one-hundred year history, America's community colleges have become highly responsive to labor market conditions. Community colleges have become key players in economic and workforce development initiatives. Changing economic conditions is a strong theme that continually appears in the literature. Many of the changing demands being placed on community and technical colleges are a result of changing economic conditions. Understanding economic change and its effect on labor markets and the employer demand for skills is vital. It is clear that one of the fundamental tasks for community colleges is to develop 
demand-based programs that incorporate new and more effective ways to combine work and learning - to enable work while learning and to acknowledge learning that occurs while working.

One common thread that runs through the literature is that community colleges must equip people with the knowledge and skills to be productive. Today's workplace is made up of global competition, advanced technology, diversity in the workforce and the emerging conversion of two generations into retirement (Gunderson, 2005). In this regard, community colleges are one of numerous partners coordinating efforts and resources for the benefit of many. From basic skills to English as a learned language, to transfer degrees, skill certification, and customized curricula for employers, community colleges are major players in workforce development around the country (Myran, Baker, Simone, \& Zeiss, 2003).

Community colleges are well positioned to assist their service areas or communities with attracting, training, and retaining a skilled workforce. Myran et al. (2003) state the following: Almost everything community colleges do is related to workforce development. With the exception of avocational courses, the entire curriculum focuses on the teaching and learning of career-related knowledge and skills. A growing number of students in the arts, humanities, sciences, professions, and technologies are seeking the knowledge and skills to help them with their careers, with an emphasis on careers and jobs that pay well and will lead to prosperity for individuals and communities. (p. 75)

\section{Development of the Seven Dimensions of College Life}

In order to identify the dimensions of college life that support labor market responsiveness, the U.S. Department of Education, Office of Vocational and Adult Education, studied labor market responsiveness at 30 community colleges nationwide. Through analyzing case studies, reviewing literature, and conducting interviews with community college leaders, 
economic development leaders, and employers they identified seven characteristics shared among these community colleges (MacAllum et al. 2004).

A $\mathrm{m}$ arket-responsive comm unity college re sponds to the training, education and employment needs of the local workforce. As Dr ury (2001) phrased it, "community colleges, for many reasons, are $\mathrm{m}$ oving to the forefront of workforce and econom ic developm ent due primarily to their location at the grass-roots level in thei $r$ service regions." Through the Community College Labor Market Responsiveness Initiative, the U.S. Department of Education, Office of Vocational and Adult Education, determ ined that market responsive community colleges share several key elements. These key elements are (a) leadership dedicated to the goal of creating $\mathrm{m}$ arket responsive co llege, (b) internal response system s, (c) business and other partnerships, and (d) connection to the local economy.

The literature suggests that these are the el ements community colleges should focus on if they aspire to become market responsive. The seven dimensions of college life flow from these four elements. Each of the seven dimensions are described in the following sections.

Leadership and governance. The most signif icant in ternal inf luence on community college governance is the for mal organization with the president at its center. State governm ent is a critical external influence that has incr eased over the years (Vaughan, 2006). The president works closely with an executive team or cabinet as well as a governing board or board of trustees.

According to the literature, for a market re sponsive community college to be succes sful, the leadership of the college needs to be committed to the development and growth of a marketresponsive approach. The comm unity college pr esident must have support of the board or governing body of the college. The president must also have an appreciation of the national 
labor market. The president needs to understand how the national labor market influences the local labor market and how the community college plays a role in developing and supporting the local economy.

One of the ways th at th e leadership can dem onstrate comm itment to market responsiveness is to iden tify this dim ension as part of th e college's $m$ ission. By expanding the college's m ission, the leadersh ip is comm itting itself to providing sup port to the local and national workforce. This action demonstrates willingness to develop and deliver training to local employers and e mployees (Bailey and Aver ianova, 1998; Carnevale, 2000; W arford \& Flynn, 2002).

The literature stresses that fi rst-hand knowledge of local ec onomy needs is essential for community colleg es to be able to $\mathrm{p}$ lan and im plement effective train ing programs. Community college leaders should infor $\mathrm{m}$ the mselves about economic and workforce trends and act as an instrument for bringing inform ation back to campus a nd put this inform ation into action (MacAllum et al. 2004). Rapidly changing technology influences the economy within a college's service a rea. Job des criptions a re not $\mathrm{s}$ tatic and em ployees need sk ills in $\mathrm{m}$ ore than one discipline. A comm unity college that understands this dynam ic change and delivers training appropriate for the local workforce is a valuable asset to businesses in the region (Cantor, 2002; National Alliance of Business, 2001).

Organizational structure and staffing. The reporting structure of a community college reflects its priorities, and this is reflected in the senior administration. Responsive colleges have an internal division committed to responding to training needs of the local economy and employers. However, no one division should hold singular responsibility for an institution's labor market responsiveness (MacAllum et al. 2004). Separate divisions, or rapid response 
teams, within the community college develop and deliver training to meet local employments needs. This structure permits a college to become market responsive without creating deep changes in its traditional structure. Creating a workforce development division, whether as part of the existing college structure or as a stand-alone entity, increases the visibility of the college as a training provider as well as enables the college to become more nimble in developing and delivering training to employers and others seeking to improve job skills (Drury, 2001; Grubb et al. 1997; Liebowitz et al. 2001).

The literature explains that a labor market responsive community college builds bridges across the traditional credit-noncredit divide. Faculty and staff collaborate across these divisions in mutually supportive ways. Much of the curricula developed for non-credit courses can benefit students in credit programs. Occupational non-credit programs address the needs of employers and students seeking employment. Many of the competencies developed for these courses are relevant for students seeking degrees or certificates. Responsive community colleges utilize the competencies developed in non-credit courses to update credit programs to closely match labor market requirements (Brewer \& Gray, 1997; Cantor, 2002; Drury, 2001; Lebowitz et al 2001).

Organizational culture. The organizational culture of a labor market responsive community college is entrepreneurial, flexible, innovative, and collaborative. In responsive colleges, faculty and staff work together to respond to diverse cultures and changing student populations in their communities. New values, attitudes and orientation toward marketresponsive activities prevail over traditional mindsets (MacAllum et al. 2004). This is reflected in the following statement by Flynn (2005):

What is the infrastructure of a college? Essentially, it is the sum of its relationships, transactions and interactions, individually and collectively. It is how we deal with each 
other, how we treat students and colleagues. How we have, over time, identified and claimed curricular, political and procedural turf. Eventually, it is how our collective and remembered interactions evolve into that intangible, yet pervasive thing we call organizational culture. (p. 18)

The organizational culture of a labor market responsive community college embraces collaboration and communication. Many community colleges depend on a workforce development or continuing education division to provide specialized or customized training to business and industry. These divisions may look somewhat different from one institution to another. In labor market responsive community colleges, faculty and staff from all divisions work together to develop and deliver services and curriculum to meet employer's needs. Such collaborative endeavors expand the capabilities of the community college (Drury, 2001; Pindar, 1999; Seppanen, 1991). As Flynn (2005) aptly states, "responding as individual divisions is one thing; responding collectively, aligned in a strong institutional commitment to meeting workforce needs, is quite another" (p. 12).

Resources and funding. Successful labor market responsiveness requires sufficient resources. Competition for public funds for higher education continues to increase. Building financial capacity is an essential building block in achieving the college's mission (Myran, 2003). Responsive community colleges seek and utilize a variety of resources beyond state funding. These resources can include grants, special state initiatives, federal funds, in-kind donations, and contributions from employer partnerships (MacAllum et al. 2004). For example, in West Virginia the public community and technical colleges are provided opportunities to apply for state funded competitive grants. These grants encourage the colleges to seek, develop, 
and nurture strong partnerships with local business and industry in order to fund workforce development related projects and programs.

Labor market responsive community colleges are creative and entrepreneurial in fundraising. According to Grubb (2001), how community colleges respond to the growing demand for employer training determines how effective they will be at securing training dollars from employers and students. In labor market responsive community colleges, the employer is considered the primary customer. Customizing coursework to meet specific employer needs and providing college services on a fee-for-service basis are ways of increasing financial resources.

Community colleges supplement their operating budgets by establishing educational foundations. Foundations are incorporated to receive endowments and other types of funds for use by the community college with which they are affiliated (Vaughan, 2006). A foundation is a partner with the college leadership in raising funds for student scholarships, instructional equipment, capital projects, and other initiatives that meet the interests of donors (Myran, 2003).

Information and data. Gathering current information for decision making and strategic planning is a theme that runs through the literature. Personal communication with local employers and economic development authorities are vital for gathering up-to-the minute information on local needs and trends (MacAllum et al. 2004). This personal contact with local employers provides community colleges with valuable information regarding specific labor needs and trends. Colleges that demonstrate they can successfully recruit and train students in highly sought-after skills become attractive as training resources to local businesses (Salter, 1999; Seppanen, 1991). Community colleges must conduct environmental scans and rely on data to determine which programs may no longer be relevant to the workforce and which programs support employers' current and emerging workforce needs. 
Relationship building. The president, board, and workforce development division of the college take the lead on forming and maintaining relationships with the institutions constituencies. Labor market responsive community colleges realize that it is the responsibility of everyone, including faculty and administrators to take an active stance in reaching out to the community (MacAllum et al. 2004). Community colleges reach out to the areas they serve in many ways. Advisory committees are the cornerstone of an institution's effort to maintain responsiveness to local labor markets (Brewer \& Gray, 1997). Advisory committees link community college faculty directly to local business and industry.

While community colleges focus much of their energy on working with local businesses, they also understand that success in meeting labor market needs often requires forming strategic alliances with their constituencies. Most community colleges form strategic relationships with local chambers of commerce, economic development organizations, service organizations, small business networks, and workforce development groups.

Relationship building is everyone's job at a labor market responsive community college. Relationships are formed through outreach, and it is through outreach efforts that a community college can promote its mission. Mission and vision statements, strategic plans, and college team members help to promote the message that a community college is a responsive and flexible economic development partner (MacAllum et al. 2004).

Partnerships. Labor market responsive community colleges partner with employers and associations based on strategic priorities (MacAllum et al. 2004). Community colleges assess local workforce needs and then determine how best the college can meet these needs. Community colleges have the ability to develop customized training and degrees that are 
critically important in local and regional economic development initiatives (Campbell \& Long, 2007).

Businesses find partnerships with community colleges attractive because community colleges can develop and deliver large-scale, complex and long-term training and provide full and part-time faculty to help develop and teach courses (National Alliance of Business, Inc., 2001). Both community colleges and businesses mutually benefit from partnerships. When the two organizations join forces to develop programs to train and prepare workers, local businesses receive a steady supply of highly-trained and qualified employees. At the same time, community colleges can incorporate the new programs, modules, or technologies into their own curricula and increase capacity to train additional students and other employers.

Businesses offer leadership in partnerships with community colleges by supplying subject matter experts to assist in developing programs and courses. Businesses also demonstrate leadership by participating in advisory committees and providing valuable information when assessing the effectiveness of training programs.

In addition to partnering with businesses, responsive community colleges seek creative and resourceful ways of expanding their service capabilities by creating partnerships with other local educational institutions. By collaborating with other educational institutions in curriculum development and training delivery, community colleges are able to maximize their resources while better serving companies that populate specific industries (Salter, 1999).

In summary, the literature describes that a labor market-responsive community college must develop and align the seven key dimensions: leadership and governance, organizational structure and staffing, organizational culture, resources and funding, information and data, relationship building, and strategic partnerships. 


\section{CHAPTER 3: METHODOLOGY}

This chapter describes the methodology that was used for the study. This chapter is divided into four sections. The first section describes the research design. The second section describes the participants. The third section describes the instrumentation. The final section describes the research procedures.

\section{Research Design}

Descriptive research was used to determine to what extent the presidents of the ten public community and technical colleges within the state of West Virginia perceive their institutions implementing the seven dimensions of college life in support of labor market responsiveness. This method was selected because a descriptive study determines and describes the way things are (Gay \& Airasian, 2003). This study utilized the seven dimensions of labor market responsiveness identified by the U.S. Department of Education, Office of Vocational and Adult Education. The following questions guided this study:

1. What is the extent to which West Virginia's public community and technical college presidents perceive their institutions as exhibiting leadership and governance?

2. What is the extent to which West Virginia's public community and technical college presidents perceive their institutions as having appropriate organizational structure and staffing?

3. What is the extent to which West Virginia's public community and technical college presidents perceive their institutions as exhibiting supportive organizational culture?

4. What is the extent to which West Virginia's public community and technical college presidents perceive their institution's allocation of resources and funding to be sufficient? 
5. What is the extent to which West Virginia's public community and technical college presidents perceive their institutions as utilizing information and data?

6. What is the extent to which West Virginia's public community and technical college presidents perceive their institutions as building relationships with their relevant constituencies?

7. What is the extent to which West Virginia's public community and technical college presidents perceive their institutions as establishing partnerships with local employers and economic development agencies?

8. Is there a relationship between the extent to which the presidents perceive their institutions as implementing the seven dimensions of college life supporting labor market responsiveness and the institutional factors of (a) size of institution based on student FTE, (b) number of counties in the service area, and (c) annual operating budget?

9. Is there a relationship between the extent to which the presidents perceive their institutions as implementing the seven dimensions of labor market responsiveness and the presidents' demographics?

\section{Participants}

There are ten public community and technical colleges in the state of West Virginia. The West Virginia community and technical colleges, their consortium service districts, and inclusive counties are shown in Appendix A. West Virginia's ten public community and technical colleges are organized into eight consortium districts. These consortium districts overlap counties and create an environment where some community and technical colleges provide services to several of the same counties. 
The participants in this study were the presidents of each public community and technical college in West Virginia. Creating a culture of labor market responsiveness within a community college begins with the president. The president can be described as the architect who designs the community college (Myran, Baker, Simone \& Zeiss 2003). Therefore, the president at each of the ten public community and technical colleges were asked to participate in this study. The West Virginia community and technical college presidents are described using demographic data.

\section{Demographics of Presidents}

The participants responded to eight dem ographic questions. Three or $30 \%$ of the presidents were female. Seven or $70 \%$ of the presidents were male. Table 4.2 shows the gender and age ranges reported by the participants.

Table 3-1 Gender and Age Range of Presidents

\section{Age Ranges}

\begin{tabular}{lll} 
Gender & $45-55$ & $56-65$ \\
\hline Male 1 & & 6 \\
Female & 2 & 1
\end{tabular}

Five $(50 \%)$ of the presidents reported an Ed.D. as their highest degree earned. Two $(20 \%)$ of the presidents reported a Ph.D. and three (30\%) reported an M.A. as their highest degree earned. Of the ten presidents, seven (70\%) reported education as their highest degree earned. Three (30\%) reported a field other than education as their highest degree earned. These three fields include English, Philosophy, and Journalism. 
The participants repo rted their s ervice as president of th eir curren t community and technical college from $6 \mathrm{~m}$ onths to 13 years. The averag e length of tim e spent serving as a presdient $\mathrm{w}$ as 4.2 years $(\mathrm{SD}=.4)$. The total $\mathrm{y} \quad$ ears of experience as an adm inistrator in a community and technical college ranged from 6 months to 34 years. The average for experience as an administrator in a community and technical college was 19.25 years $(\mathrm{SD}=.5)$.

\section{Demographics of Community and Technical Colleges}

This study utilized three $\mathrm{f}$ actors regarding institutional si ze. The size of the community and technical colleges represented by the re spondents was based on the student full-tim e equivalency (FTE) count from the Fall 2007 academ ic sem ester. T he s econd factor was the number of counties in the institution's service area, and the third factor was the institution's 2007 annual operating budget. Table 4.1 shows the ten West Virginia public community and technical colleges and their size based on 2007 student FT E, number of counties in their service areas, and their 2007 annual operating budget.

The average student FTE for the c ommunity and technical colleges $\mathrm{w}$ as $1,377(\mathrm{SD}=$ 675). The average num ber of count ies within a community and tech nical college's service area was $6.5(\mathrm{SD}=2.8)$. The average 2007 annual operating budget of all institutions was $\$ 5,470,000$ $(\mathrm{SD}=\$ 2,530,000)$ 
Table 3-2 Community and Technical College 2007 Demographics

\begin{tabular}{llcc}
\hline Community and Technical College & $\begin{array}{l}\text { Student } \\
\text { FTE }\end{array}$ & $\begin{array}{l}\text { Counties in } \\
\text { Service Area }\end{array}$ & $\begin{array}{l}\text { Operating } \\
\text { Budget }\end{array}$ \\
\hline Blue Ridge Community and Technical College & 1,006 & 3 & $2,871,929$ \\
Community and Technical College at WVU Tech & 615 & 5 & $3,404,908$ \\
Eastern WV Community and Technical College & 206 & 6 & $2,021,567$ \\
Marshall Community and Technical College & 1,485 & 4 & $5,711,590$ \\
New River Community and Technical College & 1,376 & 9 & $4,801,282$ \\
Pierpont Community and Technical College & 1,798 & 13 & $8,114,815$ \\
Southern WV Community and Technical College & 1,616 & 6 & $8,386,234$ \\
WV Northern Community and Technical College & 1,856 & 5 & $7,009,680$ \\
WV State Community and Technical College & 1,205 & 7 & $3,418,827$ \\
WVU at Parkersburg & 2,606 & 7 & $8,953,448$ \\
\hline
\end{tabular}

The presidents reported the year th eir community and tech nical college was established. The first community and technical college was established in 1961. This institution was W VU Parkersburg which was adm inistratively linked to W est Virginia Un iversity. Although the first institution was created as a branch cam pus in 1901, W VU Parkersburg wa s established through legislation passed in 1961. The tenth community and technical college was established in 2003. This was New River Comm unity and Technical College which was adm inistratively linked to Bluefield State Colleg e. Six (60\%) of the community and technica 1 co lleges were administratively linked to baccalaureate ins titutions. Three (30\%) of the community and technical colleges were free s tanding and i ndependently accredited. One (10\%) of th e community and technical colleges was free standing not independently accredited. 


\section{Instrumentation}

The instrument used for the purpose of this study, Assessing Seven Dimensions of the College to Improve Labor Market Responsiveness, was designed by the U.S. Department of Education, Office of Vocational and Adult Education as a self-assessment tool. This selfassessment questionnaire focused on the seven dimensions of college life that are shared by market responsive community colleges. This questionnaire is found in Appendix B. The seven dimensions are (a) leadership and governance, (b) organizational structure and staffing, (c) organizational culture, (d) resources and funding, (e) information and data, (f) relationship building, and (g) partnerships.

The questionnaire, developed by the U.S. Department of Education, Office of Vocational and Adult Education, was designed to serve as a tool to assist college leaders in assessing the practices, structures, and activities of their institutions for the purpose of creating a labor market responsive community college (MacAllum et al. 2004). This tool focused directly on each of the seven dimensions and was designed to help community colleges reflect on internal structures, policies, and practices that diminish or advance labor market responsiveness.

In order to develop the seven dimensions used in the questionnaire, the U.S. Department of Education, Office of Vocational and Adult Education, studied labor market responsiveness at 30 community colleges nationwide. Through analyzing case studies and conducting interviews with community college leaders, economic development leaders, and employers they identified seven characteristics shared among these community colleges. These seven characteristics or dimensions of college life support labor market responsiveness (MacAllum et al. 2004).

The presidents were asked to assess their institution's level of labor market responsiveness with each of the dimensions on a five point scale (1-5, very low to very high). 
The Likert scale is often used to measure attitudes (Gay \& Airasian, 2003, p.131). This scale asks for the extent of agreement with an attitude item (Likert, 1932). The participant's scores were calculated using a five point Likert scale with the following values: $1=$ not at all, $2=$ slightly, $3=$ somewhat, $4=$ almost always, and 5=completely. Items that were rated at a 1, 2, or 3 and dimensions with low ratings highlight areas that may impede labor market responsiveness. The full questionnaire is located in Appendix B.

The instrument for this study was adapted to include the demographic questions in the second section. The second section of the questionnaire was designed to gather personal data from the participants to include years served as president, years of experience as a community college administrator, whether or not the community and technical college was linked to another institution, the highest degree earned, the field of highest degree, age and gender. In addition to the instrument, data was obtained from the 2007 Higher Education Report Card to describe (a) size of each institution based on Fall 2007 student FTE, (b) number of counties in the service area for each institution, and (c) annual operating budget for each institution.

\section{Procedure}

The instrument was developed an as online survey using SimpleForms, a web-based software which is supported by the West Virginia University Office of Information Technology and West Virginia University Web Services. Appendix B contains a copy of this survey. A letter that describes the study and contains instructions for completing the on-line survey was mailed to each participant. A copy of this letter is found in Appendix C. A letter of support from the Chancellor of the West Virginia Council for Community and Technical College Education accompanied the letter mailed to each participant. A copy of this letter is in Appendix 
D. An e-mail was sent to participants containing the survey link. An e-mail was sent to participants who did not respond to the first request to complete the survey.

This instrument used in this research study generated ordinal data. The participant's responses were ranked using a Likert scale according to the following values: $1=$ not at all, $2=$ slightly, $3=$ somewhat, $4=$ almost always, and $5=$ completely. According to Gay and Airasian (2003), ordinal variables "allow the researcher to describe performance as higher or lower, they do not indicate how much higher one person performed compared to another." An ordinal variable can rank person or objects. However, it does not have equal scale intervals.

The data are presented with frequency distributions to represent participants' responses for research questions one through seven. The descriptive statistics used in this study include mean, standard deviation, median, and range. Cronbach's alpha was used to test the survey's internal consistency. The Spearman correlation coefficient was used to address research question eight. The Spearman correlation coefficient was used to describe the relationship between the participants' perceptions of the seven dimensions of college life, which support labor market responsiveness and their institutions 2007 student full-time equivalency (FTE) count, number of counties in their service areas, and annual operating budget. The study utilized the institution's annual operating budget as allocated by the state of West Virginia in the 2007 Higher Education Report Card. This budget data is a state allocation and does not include an institution's total revenue. Therefore, is not representative of an institution's total annual budget or per student expenditure.

Cohen's $\quad d$ was used to address research question nine. Cohen's $d$ is a direct method for measuring effect size (Gravetter \& Wallnau, 2004, p. 261). Effect size is the measure of the strength of the relationship between two variables. This statistical treatment was chosen to 
measure the strength of the relationship between the participants' perceptions of the seven dimensions of college life which support labor market responsiveness and the participants' demographics. Two separate groups were formed for each variable and Cohen's $d$ was used to describe the size of the difference between those two groups. 


\section{CHAPTER 4: RESULTS}

This study examined the extent the presiden ts of the ten public co mmunity and technical colleges within the state of W est Virginia per ceived their in stitutions as able to im plement the seven dim ensions of college life in support of labor $\mathrm{m}$ arket responsiveness. This chapter describes th e data collected relative to th e de mographic features of the institutions, the demographic features of the presidents, and the seven dimensions of college life which support labor market responsiveness. All ten presiden ts of each public community and techn ical college in West Virginia completed the on-line survey. This yielded a response rate of $100 \%$.

\section{Research Questions}

The first seven research questions listed statements under each question. The participants rated the statements using a Likert scale. This chapter includes a frequency distribution table and a descriptive statistics table for research questions one through seven.

\section{Research Question 1}

The first research question was, "What is the extent to which the West Virginia community and technical college presidents perceive their institutions exhibiting leadership and governance?" The participants rated 10 statements regarding leadership and governance using a Likert scale. The frequency distribution for each statement is found in Table 4.3. The descriptive statistics are found in Table 4.4.

The highest mean of leadership and governance frequencies was shared by two statements. These are statements number 2; labor market responsiveness is reflected in the college mission statement, and statement number 6; leaders portray the college as an economic development partner to the community. The mean for these statements was $4.4(\mathrm{SD}=.6)$. Both of these share 
the same distribution of frequencies. In this first research question, the most consistency or least amount of variability was found within these two statements.

The lowest mean found in this first research question was statement number 5; leaders maintain a vision beyond the traditional service area. The mean for this statement was $3.7(\mathrm{SD}=$ .8). The most variability or least consistency was found in statement number 3; leaders, especially the board and president, are fully and publicly committed to a labor market-responsive mission. The mean for this statement was $4.3(\mathrm{SD}=1.0)$. 
Table 4-1 Leadership and Governance Frequencies

\begin{tabular}{|c|c|c|c|c|c|}
\hline \multirow{3}{*}{$N=10$} & \multicolumn{5}{|c|}{ Frequency } \\
\hline & & & Somewhat & $\begin{array}{l}\text { Almost } \\
\text { always }\end{array}$ & Completely \\
\hline & 1 & 2 & 345 & & \\
\hline $\begin{array}{l}\text { College leadership is shared among } \\
\text { multiple people. }\end{array}$ & 0 & 0 & 352 & & \\
\hline $\begin{array}{l}\text { Labor market responsiveness is } \\
\text { reflected in the college mission } \\
\text { statement. }\end{array}$ & 0 & 0 & 145 & & \\
\hline $\begin{array}{l}\text { Leaders, especially the board and } \\
\text { President, are fully and publicly } \\
\text { committed to a labor-market } \\
\text { responsive mission. }\end{array}$ & 0 & 1 & 126 & & \\
\hline $\begin{array}{l}\text { Leaders are actively involved in } \\
\text { furthering that mission. }\end{array}$ & 0 & 0 & 325 & & \\
\hline $\begin{array}{l}\text { Leaders maintain a vision beyond } \\
\text { the traditional service area. }\end{array}$ & 0 & 1 & 2 & 6 & 1 \\
\hline $\begin{array}{l}\text { Leaders portray the college as an } \\
\text { economic development partner to } \\
\text { the community. }\end{array}$ & 0 & 0 & 145 & & \\
\hline $\begin{array}{l}\text { College leaders are very visible in } \\
\text { the community. }\end{array}$ & 0 & 0 & 253 & & \\
\hline $\begin{array}{l}\text { College leaders are well informed } \\
\text { on economic and workforce trends. }\end{array}$ & 0 & 1 & 1 & 5 & 3 \\
\hline $\begin{array}{l}\text { Leaders convey local market } \\
\text { information to the broader campus. }\end{array}$ & 0 & 1 & 2 & 5 & 2 \\
\hline $\begin{array}{l}\text { Leadership style is passionate, } \\
\text { innovative, anticipatory, and } \\
\text { entrepreneurial. }\end{array}$ & 0 & 0 & 244 & & \\
\hline
\end{tabular}


Table 4-2 Leadership and Governance Descriptive Statistics

\begin{tabular}{|c|c|c|c|c|}
\hline $\mathrm{N}=10$ & Mean & SD & Median & Range \\
\hline $\begin{array}{l}\text { College leadership is shared among } \\
\text { multiple people. }\end{array}$ & 3.9 & .7 & 4.0 & 2 \\
\hline $\begin{array}{l}\text { Labor market responsiveness is } \\
\text { reflected in the college mission } \\
\text { statement. }\end{array}$ & 4.4 & .6 & 4.0 & 2 \\
\hline $\begin{array}{l}\text { Leaders, especially the board and } \\
\text { President, are fully and publicly } \\
\text { committed to a labor-market } \\
\text { responsive mission. }\end{array}$ & 4.3 & 1.0 & 5.0 & 3 \\
\hline $\begin{array}{l}\text { Leaders are actively involved in } \\
\text { furthering that mission. }\end{array}$ & 4.2 & .9 & 4.5 & 2 \\
\hline $\begin{array}{l}\text { Leaders maintain a vision beyond the } \\
\text { traditional service area. }\end{array}$ & 3.7 & .8 & 4.0 & 3 \\
\hline $\begin{array}{l}\text { Leaders portray the college as an } \\
\text { economic development partner to the } \\
\text { community. }\end{array}$ & 4.4 & 6 & 4.5 & 2 \\
\hline $\begin{array}{l}\text { College leaders are very visible in the } \\
\text { community. }\end{array}$ & 4.1 & .7 & 4.0 & 2 \\
\hline $\begin{array}{l}\text { College leaders are well informed on } \\
\text { economic and workforce trends. }\end{array}$ & 4.0 & .9 & 4.0 & 3 \\
\hline $\begin{array}{l}\text { Leaders convey local market } \\
\text { information to the broader campus. }\end{array}$ & 3.8 & .9 & 4.0 & 3 \\
\hline $\begin{array}{l}\text { Leadership style is passionate, } \\
\text { innovative, anticipatory, and } \\
\text { entrepreneurial. } 4.2\end{array}$ & & .7 & 4.0 & 2 \\
\hline Total scale mean & 4.1 & & & \\
\hline
\end{tabular}




\section{Research Question 2}

The second research question was, "What is the extent to which the West Virginia community and technical college presidents perceive their institutions as having appropriate organizational structures and staffing?" The participants rated 7 statements regarding organizational structures and staffing using a Likert scale. The frequency distribution for each statement is found in Table 4.5. The descriptive statistics are found in Table 4.6.

The highest mean in organizational structures and staffing frequencies was found in statement number 7; program development, outreach, and interaction are considered everyone's job. This mean was $4.3(\mathrm{SD}=.9)$. The lowest mean found in this research question was for statement number 6; human resources are deployed in the most efficient manner to meet labormarket responsive goals. The mean for this statement was $3.4(\mathrm{SD}=.6)$.

The least consistency was found in statement number 3; campus structure facilitates communication and access to the human and financial resources essential for labor-market responsive activities. The mean for this statement was $3.5(\mathrm{SD}=1.1)$. The most consistency was found in statement 2; the college's organizational charts and staffing structure reflect the equal importance of credit and noncredit programs. 
Table 4-3 Organizational Structure and Staffing Frequencies

\begin{tabular}{|c|c|c|c|c|c|}
\hline \multirow[b]{2}{*}{$\mathrm{N}=10$} & \multicolumn{4}{|c|}{ Frequency } & \multirow{3}{*}{$\begin{array}{c}\text { Completely } \\
5 \\
\end{array}$} \\
\hline & $\begin{array}{c}\text { Not at } \\
\text { all }\end{array}$ & Slightly Som & ewhat & $\begin{array}{l}\text { Almost } \\
\text { always }\end{array}$ & \\
\hline 1 & & 2 & 3 & 4 & \\
\hline $\begin{array}{l}\text { The organizational chart and } \\
\text { staffing structure of the community } \\
\text { college reflect a commitment to } \\
\text { labor-market responsive services } \\
\text { and programs. }\end{array}$ & 0 & 0 & 4 & 4 & 2 \\
\hline $\begin{array}{l}\text { The college's organizational chart } \\
\text { and staffing structure reflect the } \\
\text { equal importance of credit and } \\
\text { noncredit programs. }\end{array}$ & 0 & 0 & 0 & 8 & 2 \\
\hline $\begin{array}{l}\text { Campus structure facilitates } \\
\text { communication and access to the } \\
\text { human and financial resources } \\
\text { essential for labor-market } \\
\text { responsive activities. }\end{array}$ & 1 & 0 & 4 & 3 & 2 \\
\hline $\begin{array}{l}\text { Credit and noncredit programs and } \\
\text { their faculties collaborate to } \\
\text { develop and deliver career-oriented } \\
\text { training. } 1\end{array}$ & & 0 & 3 & 4 & 2 \\
\hline $\begin{array}{l}\text { Close working relationships } \\
\text { between the credit and noncredit } \\
\text { sides of the college enhance the } \\
\text { college's ability to provide labor- } \\
\text { market responsive programs. }\end{array}$ & 0 & 0 & 3 & 5 & 2 \\
\hline $\begin{array}{l}\text { Human resources are deployed in } \\
\text { the most efficient manner to meet } \\
\text { labor-market responsive goals. }\end{array}$ & 1 & 0 & 4 & 5 & 0 \\
\hline $\begin{array}{l}\text { Program development, outreach, } \\
\text { and interaction are considered } \\
\text { everyone's job. }\end{array}$ & 0 & 0 & 3 & 1 & 6 \\
\hline
\end{tabular}


Table 4-4 Organizational Structure and Staffing Descriptive Statistics

\begin{tabular}{|c|c|c|c|c|}
\hline $\mathrm{N}=10$ & Mean & SD & Median & Range \\
\hline $\begin{array}{l}\text { The organizational chart and staffing } \\
\text { structure of the community college } \\
\text { reflect a commitment to labor-market } \\
\text { responsive services and programs. }\end{array}$ & 3.8 & .7 & 4.0 & 2 \\
\hline $\begin{array}{l}\text { The college's organizational chart and } \\
\text { staffing structure reflect the equal } \\
\text { importance of credit and noncredit } \\
\text { programs. }\end{array}$ & 4.2 & .4 & 4.0 & 1 \\
\hline $\begin{array}{l}\text { Campus structure facilitates } \\
\text { communication and access to the } \\
\text { human and financial resources } \\
\text { essential for labor-market responsive } \\
\text { activities. } 3.5\end{array}$ & & 1.1 & 3.5 & 4 \\
\hline $\begin{array}{l}\text { Credit and noncredit programs and } \\
\text { their faculties collaborate to develop } \\
\text { and deliver career-oriented training. }\end{array}$ & 3.7 & .9 & 4.0 & 3 \\
\hline $\begin{array}{l}\text { Close working relationships between } \\
\text { the credit and noncredit sides of the } \\
\text { college enhance the college's ability to } \\
\text { provide labor-market responsive } \\
\text { programs. }\end{array}$ & 3.9 & .7 & 4.0 & 2 \\
\hline $\begin{array}{l}\text { Human resources are deployed in the } \\
\text { most efficient manner to meet labor- } \\
\text { market responsive goals. }\end{array}$ & 3.4 & .6 & 3.5 & 2 \\
\hline $\begin{array}{l}\text { Program development, outreach, and } \\
\text { interaction are considered everyone's } \\
\text { job. } 4.3\end{array}$ & & .9 & 5.0 & 2 \\
\hline Total scale mean & 3.8 & & & \\
\hline
\end{tabular}




\section{Research Question 3}

The third research question was, "What is the extent to which the West Virginia community and technical college presidents perceive their institutions exhibiting supportive organizational culture?" The participants rated 7 statements regarding organizational culture using a Likert scale. The frequency distribution for each statement is found in Table 4.7. The descriptive statistics are found in Table 4.8.

The highest mean of organizational culture was found in statement number 6; there is a willingness to work closely with representatives from business and industry in the design, development, and delivery of education and training. The mean for this statement was $4.5(\mathrm{SD}=$ .7). The lowest mean in research question 3 was found in statement 7; college leaders, faculty, and staff share a common understanding of the proper balance of the college's multiple missions. The mean for this statement was $3.8(\mathrm{SD}=.7)$.

The least consistency was shared by two statements. These are statements number 2 ; the college is characterized by flexibility, innovation, collaboration, and entrepreneurship and statements number 3; the college has a motto or theme that focuses attention on the mission of workforce and economic development. Both of these statements shared the same frequencies. The mean for both of these statements was $3.9(\mathrm{SD}=1.2)$.

The most consistency was found in statement 4; leaders and staff are open to change, committed to serving students and employers, and respectful of workplace culture. The mean for this statement was $4.2(\mathrm{SD}=.6)$. 
Table 4-5 Organizational Culture Frequencies

\begin{tabular}{|c|c|c|c|c|c|}
\hline \multirow[b]{2}{*}{$N=10$} & \multicolumn{4}{|c|}{ Frequency } & \multirow[b]{2}{*}{ Completely } \\
\hline & $\begin{array}{c}\text { Not at } \\
\text { all }\end{array}$ & Slightly Som & ewhat & $\begin{array}{l}\text { Almost } \\
\text { always }\end{array}$ & \\
\hline 1 & & 2 & 3 & 4 & 5 \\
\hline
\end{tabular}

A strong belief system embraces labor market responsiveness as a core mission.

0

$\begin{array}{ll}0 & 2\end{array}$

5

The college is characterized by flexibility, innovation, collaboration, and entrepreneurship.

$0 \quad 2$

3

The college has a motto or theme that focuses attention on the mission of workforce and economic development. 1

0

2

4

Leaders and staff are open to change, committed to serving students and employers, and respectful of workplace culture.

$\begin{array}{ll}0 & 1\end{array}$

3

Workforce development strategies reflect the cultures of the surrounding communities and specifically address local needs.

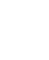

1

6

2

There is a willingness to work closely with representatives from business and industry in the design, development, and delivery of education and training. 0 $3 \quad 6$

College leaders, faculty, and staff share a common understanding of the proper balance of the college's multiple missions.

0

1

7

1


Table 4-6 Organizational Culture Descriptive Statistics

$\mathrm{N}=10$

Mean

SD

Median

Range

A strong belief system embraces labor market responsiveness as a core mission. 4.1

4.0

2

The college is characterized by flexibility, innovation, collaboration, and entrepreneurship.

4.0

4

The college has a motto or theme that focuses attention on the mission of workforce and economic development.

4.0

4

Leaders and staff are open to change, committed to serving students and employers, and respectful of workplace culture.

.6

4.0

2

Workforce development strategies reflect the cultures of the surrounding communities and specifically address local needs.

.8

4.0

3

There is a willingness to work closely with representatives from business and industry in the design, development, and delivery of education and training.

.7

5.0

2

College leaders, faculty, and staff share a common understanding of the proper balance of the college's multiple missions. 


\section{Research Question 4}

The fourth research question was, "What is the extent to which the West Virginia community and technical college presidents perceive their institution's allocation of resources and funding to be sufficient?" The participants rated 10 statements regarding resources and funding using a Likert scale. The frequency distribution for each statement is found in Table 4.9. The descriptive statistics are found in Table 4.10.

The highest mean of resources and funding frequencies was statement 8 ; the college president, board members, and top administrators are personally invested in developing largescale partnerships that fund responsive programs. The mean for this statement was 4.2 , and the standard deviation was .7 .

The lowest mean of resources and funding was shared by three statements. These are statement number 6; the college is successful in securing strong financial support from local sources, statement number 7; sufficient human resources are dedicated to obtaining resources that support responsive programming and services, and statement number 10; adequate resources are invested in the professional development of faculty and staff to enable them to effectively implement responsive programs. The mean for these statements was 3.6. Statements 7 and 10 shared a standard deviation of .6. Statement number 6 had the least consistency with a mean of $3.6(\mathrm{SD}=1.3)$.

The most consistency was found in statement number 9; discretionary resources are allocated equitably between academic and occupationally oriented programs. The mean for this statement was $3.8(\mathrm{SD}=.4)$. 
Table 4-7 Resources and Funding Frequencies

\begin{tabular}{|c|c|c|c|c|c|}
\hline $\mathrm{N}=10$ & $\begin{array}{c}\text { Not at all } \\
1\end{array}$ & $\begin{array}{c}\text { Slightly } \\
2\end{array}$ & $\begin{array}{r}\frac{\text { Frequency }}{\text { Somewhat }} \\
345 \\
\end{array}$ & Almost Always & Completely \\
\hline $\begin{array}{l}\text { The college aggressively pursues } \\
\text { non-state sources of income. }\end{array}$ & 1 & 0 & 2 & 3 & 4 \\
\hline $\begin{array}{l}\text { The widest possible range of funding } \\
\text { streams has been explored. }\end{array}$ & 1 & 0 & 2 & 5 & 2 \\
\hline $\begin{array}{l}\text { The college is innovative in } \\
\text { developing and embracing new } \\
\text { methods to raise funds for high- } \\
\text { demand programs. }\end{array}$ & 1 & 0 & 243 & & \\
\hline $\begin{array}{l}\text { The community college is creative in } \\
\text { seeking new sources of income to } \\
\text { finance workforce development. }\end{array}$ & 1 & 0 & 2 & 3 & 4 \\
\hline $\begin{array}{l}\text { College leadership is strategic in } \\
\text { leveraging resources and in-kind } \\
\text { donations to support and expand } \\
\text { partnerships. }\end{array}$ & 1 & 0 & 234 & & \\
\hline $\begin{array}{l}\text { The college is successful in securing } \\
\text { strong financial support from local } \\
\text { sources. }\end{array}$ & 1 & 1 & 233 & & \\
\hline $\begin{array}{l}\text { Sufficient human resources are } \\
\text { dedicated to obtaining resources that } \\
\text { support responsive programming and } \\
\text { services. }\end{array}$ & 0 & 0 & 541 & & \\
\hline $\begin{array}{l}\text { The college president, board } \\
\text { members, and top administrators are } \\
\text { personally invested in developing } \\
\text { large-scale partnerships that fund } \\
\text { responsive programs. }\end{array}$ & 0 & 0 & 2 & 4 & 4 \\
\hline $\begin{array}{l}\text { Discretionary resources are allocated } \\
\text { equitably between academic and } \\
\text { occupationally oriented programs. }\end{array}$ & 0 & 0 & 2 & 8 & 0 \\
\hline $\begin{array}{l}\text { Adequate resources are invested in } \\
\text { the professional development of } \\
\text { faculty and staff to enable them to } \\
\text { effectively implement responsive } \\
\text { programs. }\end{array}$ & 0 & 0 & 541 & & \\
\hline
\end{tabular}


Table 4-8 Resources and Funding Descriptive Statistics

\begin{tabular}{|c|c|c|c|c|}
\hline $\mathrm{N}=10$ & Mean & SD & Median & Range \\
\hline $\begin{array}{l}\text { The college aggressively pursues non- } \\
\text { state sources of income. }\end{array}$ & 3.9 & 1.2 & 4.0 & 4 \\
\hline $\begin{array}{l}\text { The widest possible range of funding } \\
\text { streams has been explored. }\end{array}$ & 3.7 & 1.1 & 3.7 & 4 \\
\hline $\begin{array}{l}\text { The college is innovative in } \\
\text { developing and embracing new } \\
\text { methods to raise funds for high- } \\
\text { demand programs. }\end{array}$ & 3.8 & 1.2 & 4.0 & 4 \\
\hline $\begin{array}{l}\text { The community college is creative in } \\
\text { seeking new sources of income to } \\
\text { finance workforce development. }\end{array}$ & 3.9 & 1.2 & 4.0 & 4 \\
\hline $\begin{array}{l}\text { College leadership is strategic in } \\
\text { leveraging resources and in-kind } \\
\text { donations to support and expand } \\
\text { partnerships. }\end{array}$ & 3.9 & 1.2 & 4.0 & 4 \\
\hline $\begin{array}{l}\text { The college is successful in securing } \\
\text { strong financial support from local } \\
\text { sources. }\end{array}$ & 3.6 & 1.3 & 4.0 & 4 \\
\hline $\begin{array}{l}\text { Sufficient human resources are } \\
\text { dedicated to obtaining resources that } \\
\text { support responsive programming and } \\
\text { services. }\end{array}$ & 3.6 & .6 & 3.5 & 2 \\
\hline $\begin{array}{l}\text { The college president, board members, } \\
\text { and top administrators are personally } \\
\text { invested in developing large-scale } \\
\text { partnerships that fund responsive } \\
\text { programs. }\end{array}$ & 4.2 & .7 & 4.0 & 2 \\
\hline $\begin{array}{l}\text { Discretionary resources are allocated } \\
\text { equitably between academic and } \\
\text { occupationally oriented programs. }\end{array}$ & 3.8 & .4 & 4.0 & 1 \\
\hline $\begin{array}{l}\text { Adequate resources are invested in the } \\
\text { professional development of faculty } \\
\text { and staff to enable them to effectively } \\
\text { implement responsive programs. }\end{array}$ & 3.6 & .6 & 3.5 & 2 \\
\hline Total scale mean & 3.8 & & & \\
\hline
\end{tabular}




\section{Research Question 5}

The fifth research question was, "What is the extent to which the West Virginia community and technical college presidents perceive their institutions utilizing information and data?" The participants rated 7 statements regarding information and data using a Likert scale. The frequency distribution for each statement is found in Table 4.11. The descriptive statistics are found in Table 4.12.

The highest mean of information and data was shared by three statements. These were statement number 3; college leaders and staff and well-informed about the needs of local business and industry and future economic trends, statement number 5; the college assesses the value of labor market responsive programming and services and these assessments lead to programmatic change, and statement number 6 ; the college evaluates the satisfaction of local businesses, partners, students, and their employers. The mean for these statements was 3.8. The standard deviation for statement 3 was .7. The standard deviation for statement 5 was .9. The standard deviation for statement 6 was 1.3. Statement 6 had the least consistency of all the statements within research question 5.

The lowest mean found in this research question was statement number 7; anticipatory thinking, based on solid information and data, pervades campus culture, informs outreach to partners, and shapes future vision. The mean for this statement was $3.4(\mathrm{SD}=.8)$. The most consistency was found in statement number 4 ; the college evaluates the impact of its marketresponsive programs and services. The mean for this statement was $3.5(\mathrm{SD}=.5)$. 
Table 4-9 Information and Data Frequencies

\section{Frequency}

$\mathrm{N}=10$
Not at all Slightly Somewhat

345

The community college relies on local information-gathering and published data to drive strategic planning for its responsive programs and services.

0

0

4

4 2

The college has cultivated a network of well-positioned leaders in the community to provide information about local needs and trends.

0

0

451

College leaders and staff are wellinformed about the needs of local business and industry and future economic trends.

0

0

The college evaluates the impact of its market-responsive programs and services.

0

0

The college assesses the value of labor market responsive programming and services and these assessments lead to programmatic change.

0

1

The college evaluates the satisfaction of local businesses, partners, students, and their employers. 1

1 134

Anticipatory thinking, based on solid information and data, pervades campus culture, informs outreach to partners, and shapes future vision.

Completely always 
Table 4-10 Information and Data Descriptive Statistics

$\mathrm{N}=10$
The community college relies on local
information-gathering and published information-gathering and published responsive programs and services.

.8

4.0

3

The college has cultivated a network of well-positioned leaders in the community to provide information about local needs and trends.

.6

4.0

2

College leaders and staff are wellinformed about the needs of local business and industry and future economic trends.

The college evaluates the impact of its market-responsive programs and services. 3.5

.5

$3.5 \quad 1$

The college assesses the value of labor market responsive programming and services and these assessments lead to programmatic change.

.9

4.0

3

The college evaluates the satisfaction of local businesses, partners, students, and their employers.

Anticipatory thinking, based on solid information and data, pervades campus culture, informs outreach to partners, and shapes future vision. 


\section{Research Question 6}

The sixth research question was, "What is the extent to which the West Virginia community and technical college presidents perceive their institutions building relationships with their relevant constituencies?" The participants rated 8 statements regarding building relationships with their relevant constituencies using a Likert scale. The frequency distribution for each statement is found in Table 4.13. The descriptive statistics are found in Table 4.14.

The highest mean of building relationships was shared between two statements. These are statement number 2 ; the college develops relationships with a wide variety of local organizations that could strengthen its ability to be responsive, and statement number 8; strategic relationship building is recognized as the foundation for establishing strategic partnerships. The mean for these statements was $4.3(\mathrm{SD}=.6)$. Both statements shared the same distribution of frequencies.

The lowest mean of building relationships was statement 7; marketing activities encourage others to approach the college as a partner. The mean for this statement was 3.6 (SD $=.6$ ). Statement 1 shared the same distribution of frequencies and the most consistency with statement number 6; the college seeks out new ways to market itself, regionally and nationally. The standard deviation for statement number 6 was .6. The least consistency in answers was shown in statement 4; relationship building is recognized as everyone's job. In this statement the mean was $4.0(\mathrm{SD}=1.1)$. 


\section{Frequency}

$\mathrm{N}=10$
Not at all Slightly Somewhat

345

The college reaches out to students, businesses, and other organizations to gather information about general economic conditions and specific employer concerns.

0

0

361

The college develops relationships with a wide variety of local organizations that could strengthen its ability to be responsive.

0

0

1

5

4

Leaders and staff take an active and aggressive stance in reaching out to the community.

0

0

253

Relationship building is recognized as everyone's job.

0

2

0

4

4

The trustees and president communicate the college's mission of labor market responsiveness in the public eye and in circles of influence.

0

1

135

The college seeks out new ways to market itself, regionally and nationally.

0

0

163

Marketing activities encourage others to approach the college as a partner.

0

1

Strategic relationship building is recognized as the foundation for establishing strategic partnerships.

$0 \quad 0$

154 
Table 4-12 Relationship Building Descriptive Statistics

\begin{tabular}{lllll}
\hline $\mathrm{N}=10$ & Mean & SD & Median & Range \\
\hline
\end{tabular}

The college reaches out to students, businesses, and other organizations to gather information about general economic conditions and specific employer concerns.

.6

4.0

2

The college develops relationships with a wide variety of local organizations that could strengthen its ability to be responsive.

.6

4.0

2

Leaders and staff take an active and aggressive stance in reaching out to the community.

2

Relationship building is recognized as everyone's job.

The trustees and president communicate the college's mission of labor market responsiveness in the public eye and in circles of influence.

The college seeks out new ways to market itself, regionally and nationally. 4.2

$\begin{array}{lll}.6 & 4.0 & 2\end{array}$

Marketing activities encourage others to approach the college as a partner.

Strategic relationship building is recognized as the foundation for establishing strategic partnerships.

\begin{tabular}{llll}
4.3 & .6 & 4.0 & 2 \\
4.0 & & & \\
\hline
\end{tabular}




\section{Research Question 7}

The seventh research question was, "What is the extent to which the West Virginia community and technical college presidents perceive their institutions establishing partnerships with local employers and economic development agencies?" The participants rated 7 statements regarding establishing partnerships with local employers and economic development agencies using a Likert scale. The frequency distribution for each statement is found in Table 4.15. The descriptive statistics are found in Table 4.16.

The highest mean of establishing partnerships with local employers and economic development agencies was shared by two statements. These are statement number 1; the college is engaged in sustained, successful employer partnerships that are responsive to the local market, and statement number 5; the college partners with large employers and innovative industries. The mean for these statements was 3.9. The standard deviation for statement number 1 was .9 and 1.1 for statement number 5. The lowest mean found in this seventh research question was in statement number 7; partnerships are assessed and maintained in proportion to the ability to leverage long-term outcomes and opportunities. The mean was $3.3(\mathrm{SD}=1.1)$.

The most consistency in this research question was found in statement number 4; the college has identified and partnered with the right mix of organizations. The mean for this statement was $3.5(\mathrm{SD}=.5)$. The least consistency in answers was found in statement number 6 ; the college encourages and rewards its staff for entrepreneurial activity. In this statement, the mean was $3.4(\mathrm{SD}=1.2)$. 
Table 4-13 Partnership Frequencies

\begin{tabular}{ccccc}
\hline $\mathrm{N}=10$ & Not at all & Slightly & $\begin{array}{c}\text { Frequency } \\
\text { Somewhat }\end{array}$ & $\begin{array}{c}\text { Almost } \\
\text { always }\end{array}$ \\
& 1 & 2 & 345 & \\
\hline
\end{tabular}

The college is engaged in sustained, successful employer partnerships that are responsive to the local market.

0

$1 \quad 243$

The college has established strategic priorities for partnership building with employers, aligned with the community's needs.

The partnerships in which your college takes part anticipate local economic development and growth.

0

0

3

6

1

The college has identified and partnered with the right mix of organizations.

0

0

550

The college partners with large employers and innovative industries.

0

1

The college encourages and rewards its staff for entrepreneurial activity.

1

3

3

2

Partnerships are assessed and maintained in proportion to the ability to leverage long-term outcomes and opportunities.

\begin{tabular}{lllll}
1 & 1 & 3 & 4 & 1 \\
\hline
\end{tabular}


Table 4-14 Partnership Descriptive Statistics

\begin{tabular}{lllll}
\hline $\mathrm{N}=10$ & Mean & SD & Median & Range \\
\hline
\end{tabular}

The college is engaged in sustained, successful employer partnerships that are responsive to the local market.

3.9

The college has established strategic priorities for partnership building with employers, aligned with the community's needs.

.8

4.0

3

The partnerships in which your college takes part anticipate local economic development and growth.

3.8

.6

4.0

2

The college has identified and partnered with the right mix of organizations. 3.5

The college partners with large employers and innovative industries.

The college encourages and rewards its staff for entrepreneurial activity.

$\begin{array}{llll}3.4 & 1.2 & 3.5 & 4\end{array}$

Partnerships are assessed and maintained in proportion to the ability to leverage long-term outcomes and opportunities. 3.3

$\begin{array}{lll}1.1 & 3.5 & 4\end{array}$


Cronbach's alpha was used to test the survey's internal consistency. Cronbach's alpha estimates the internal consistency of items in a survey instrument when administered to a particular group at a specific time for a specific purpose (Brown, 1988). Cronbach's alpha can range from 0.00 to 1.00 . The more consistent the responses, the higher Cronbach's alpha. Table 4.17 shows Cronbach's alpha for the survey questions regarding the seven dimensions of college life which support labor market responsiveness.

Table 4-15 Scale Reliability and Descriptive Statistics

\begin{tabular}{|c|c|c|c|c|c|}
\hline \multirow[t]{2}{*}{ Cronbach's } & & \multicolumn{2}{|c|}{ Mean SD } & \multirow[t]{2}{*}{ Median } & \multirow[t]{2}{*}{ Range } \\
\hline & Alpha & & & & \\
\hline Leadership and Governance & .924 .1 & & .83 & 4.22 & \\
\hline Organizational Structure and Staffing & .90 & 3.8 & .82 & 4.0 & 2 \\
\hline Organizational Culture & .904 .0 & & .90 & 4.13 & \\
\hline Resources and Funding & .94 & 3.8 & 1.02 & 3.9 & 3 \\
\hline Information and Data & .91 & 2.6 & .85 & 3.8 & 3 \\
\hline Relationship Building & .894 .1 & & .78 & 4.02 & \\
\hline Partnerships & .933 .6 & & .93 & 3.82 & \\
\hline Total scale & .993 .7 & & .88 & 3.92 & \\
\hline
\end{tabular}

Leadership and governance was the category with the highest mean of $4.1(\mathrm{SD}=.83)$. The presidents rated themselves more highly in this category. The category with the lowest mean was information and data which was $2.6(\mathrm{SD}=.85)$. The presidents rated themselves lower in this category. The category with the least consistency s was resources and funding which shows a mean of $3.8(\mathrm{SD}=1.02)$. The category with the most consistency was relationship building which shows a mean of $4.1(\mathrm{SD}=$ of .78$)$. Cronbach's alpha was near .9 for all of the seven 
dimensions, and the total scale reliability was .99 . This indicates strong reliability and that the participants answered consistently.

Figure 4.18 below represents the responses of the participants. Nine of the participants had scores clustered more closely or consistently than one of the participants. One participant appeared markedly different with scores consistently lower than the other participants. The mean for the group was above 3 . However, this participant's scores were consistently below the mean by 2 to 2.5 points.

Figure 4-16 Comparison of President's Responses

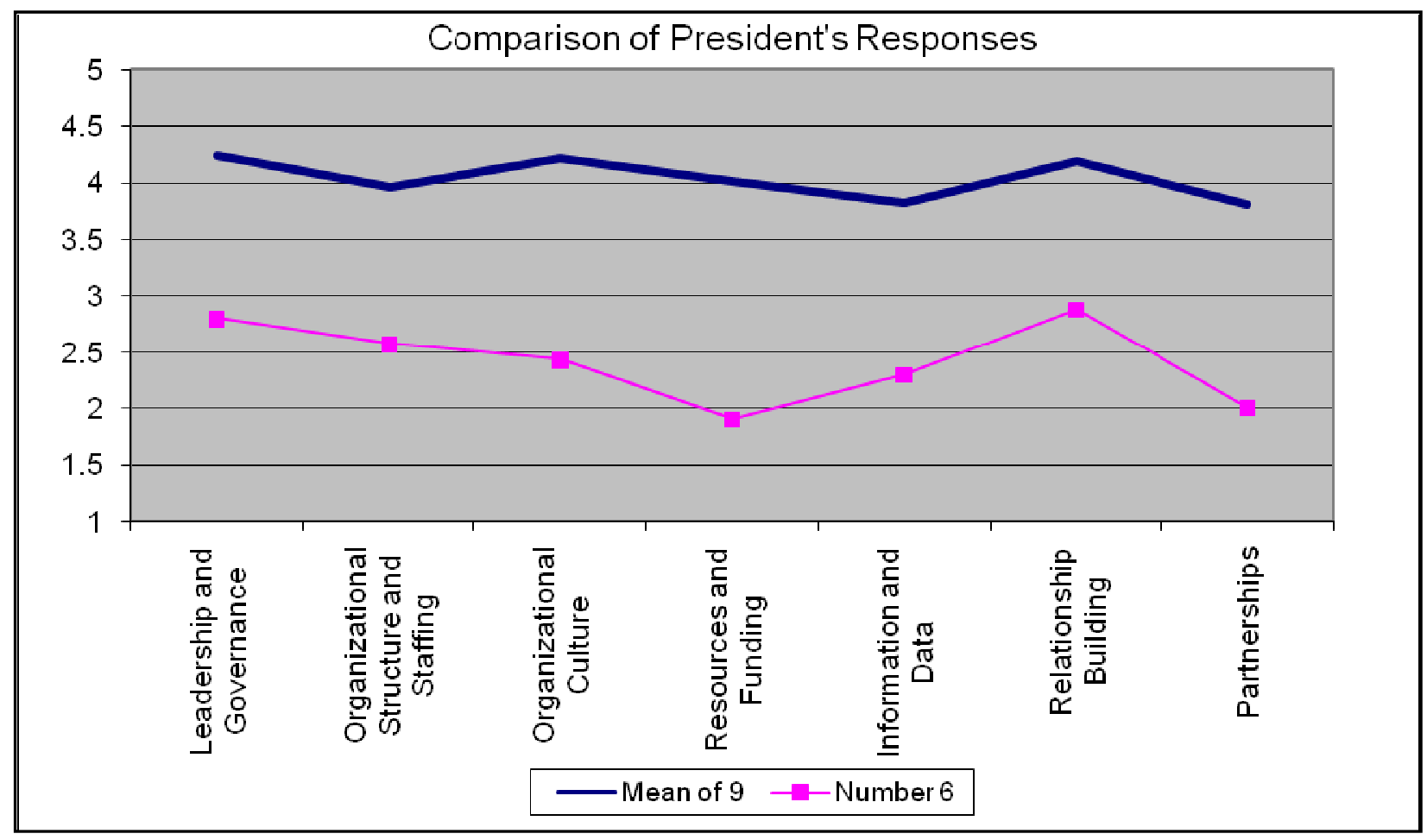




\section{Research Question 8}

The eighth research question was, "Is there a relationship between the extent to which the presidents perceive their institutions implementing the seven dimensions of college life support labor market responsiveness and the institutional factors of (a) size of institution based on student FTE, (b) number of counties in the service area, and (c) annual operating budget?" Because of the small sample size, Spearman's correlation coefficient was used to describe any relationship between the participants' perceptions of the seven dimensions labor market responsiveness and their institutions 2007 student full-time equivalency (FTE) count, number of counties in their service areas, and 2007 annual operating budget.

Table 4-17 Relationship between Perceptions and Demographics

\begin{tabular}{llll}
\hline & Student FTE & $\begin{array}{l}\text { Counties in } \\
\text { Service Area }\end{array}$ & Budget \\
\hline $\begin{array}{l}\text { Leadership and } \\
\text { Governance }\end{array}$ & $\begin{array}{l}\mathrm{r}_{\mathrm{s}}=-.11 \\
\left(\mathrm{r}^{2}=.01\right)\end{array}$ & $\begin{array}{l}\mathrm{r}_{\mathrm{s}}=-.26 \\
\left(\mathrm{r}^{2}=.07\right)\end{array}$ & $\begin{array}{l}\mathrm{r}_{\mathrm{s}}=-.23 \\
\left(\mathrm{r}^{2}=.05\right)\end{array}$ \\
$\begin{array}{l}\text { Organizational } \\
\text { Structure and }\end{array}$ & & \\
Staffing & $\mathrm{r}_{\mathrm{s}}=-.26$ & $\mathrm{r}_{\mathrm{s}}=-.12$ & $\mathrm{r}_{\mathrm{s}}=-.31$ \\
Organizational & $\left(\mathrm{r}^{2}=.07\right)$ & $\left(\mathrm{r}^{2}=.01\right)$ & $\left(\mathrm{r}^{2}=.10\right)$ \\
Culture & $\mathrm{r}_{\mathrm{s}}=-.30$ & $\mathrm{r}_{\mathrm{s}}=.04$ & $\mathrm{r}_{\mathrm{s}}=-.24$ \\
Resources and & $\left(\mathrm{r}^{2}=.09\right)$ & $\left(\mathrm{r}^{2}=.00\right)$ & $\left(\mathrm{r}^{2}=.06\right)$ \\
Funding & $\mathrm{r}_{\mathrm{s}}=-.13$ & $\mathrm{r}_{\mathrm{s}}=-.05$ & $\mathrm{r}_{\mathrm{s}}=-.10$ \\
Information and & $\left(\mathrm{r}^{2}=.02\right)$ & $\left(\mathrm{r}^{2}=.00\right)$ & $\left(\mathrm{r}^{2}=.01\right)$ \\
Data & $\mathrm{r}_{\mathrm{s}}=-.41$ & $\mathrm{r}_{\mathrm{s}}=.03$ & $\mathrm{r}_{\mathrm{s}}=-.40$ \\
Relationship & $\left(\mathrm{r}^{2}=.17\right)$ & $\left(\mathrm{r}^{2}=.00\right)$ & $\left(\mathrm{r}^{2}=.16\right)$ \\
Building & $\mathrm{r}_{\mathrm{s}}=-.25$ & $\mathrm{r}_{\mathrm{s}}=-.28$ & $\mathrm{r}_{\mathrm{s}}=-.15$ \\
& $\left(\mathrm{r}^{2}=.06\right)$ & $\left(\mathrm{r}^{2}=.08\right)$ & $\left(\mathrm{r}^{2}=.02\right)$ \\
Partnerships & $\mathrm{r}_{\mathrm{s}}=-.48$ & $\mathrm{r}_{\mathrm{s}}=-.28$ & $\mathrm{r}_{\mathrm{s}}=-.39$ \\
$\left(\mathrm{r}^{2}=.23\right)$ & $\left(\mathrm{r}^{2}=.08\right)$ & $\left(\mathrm{r}^{2}=.15\right)$ \\
\hline & $\mathrm{r}_{\mathrm{s}}=-.35$ & $\mathrm{r}_{\mathrm{s}}=-.16$ & $\mathrm{r}_{\mathrm{s}}=-.35$ \\
Total scale & $\left(\mathrm{r}^{2}=.12\right)$ & $\left(\mathrm{r}^{2}=.03\right)$ & $\left(\mathrm{r}^{2}=.12\right)$ \\
\hline
\end{tabular}

$*_{n}-10$, Due to the small sample size p-values and significance tests not included. Coefficient of determination; $r_{s}^{2}=$ proportion of shared variability. 
Firstly, participants with higher student full-time equivalency (FTE) counts evaluated their institutions lower with regard to organizational culture, information and data, and partnerships. Secondly, the number of counties within the institution's service area appeared to have a small relationship to the participants' perceptions of labor market responsiveness. Thirdly, those participants with higher institutional annual operating budgets evaluated their institutions lower with regard to organizational structure and staffing, information and data, and partnerships.

Spearman's correlation coefficient also indicated that $9 \%\left(\mathrm{r}_{\mathrm{s}}{ }^{2}=.31\right)$ of the difference in school size was related to the number of counties in the institution's service area, meaning that the number of counties had a small relationship with regard to the institutional student FTE. Secondly, $88 \%\left(\mathrm{r}_{\mathrm{s}}^{2}=.94\right)$ of the difference in student FTE was related to the difference in the institutional annual operating budgets. This was a strong positive relationship between the institutional student FTE and the institution's annual operating budget. Finally, $15 \%\left(\mathrm{r}_{\mathrm{s}}{ }^{2}=.39\right)$ of the difference in annual operating budget was related to the number of counties in the institution's service area.

\section{Research Question 9}

The ninth research question was, "Is there a relationship between the extent to which the presidents perceive their institutions implementing the seven dimensions of labor market responsiveness and the presidents' demographics?" This relationship was explored by creating two groups for each variable, one group above the mean and one group below the mean. Cohen's $d$ was chosen to measure the size of the difference between those groups. Effect size can be standardized by measuring the mean difference in terms of the standard deviation 
(Gravetter \& Wallnau, 2004, p. 261). For example, a $d$ of 0.5 equals a $1 / 2$ standard deviation difference between groups. A medium effect (with a mean difference around 0.5 standard deviation) has a magnitude of $0.2<\mathrm{d}<0.8$ and a large effect (with a mean difference around 0.8 standard deviation) has a magnitude of $d>0.8$ (Gravetter \& Wallnau, 2004, p. 261).

Table 4.20 shows the Cohen's $d$ for the participants' responses to demographic questions and the seven dimensions of college life which support labor market responsiveness. The demographic questions are found in Appendix B.

Table 4-18 Seven Characteristics and Participant Demographics

\begin{tabular}{|c|c|c|c|c|c|c|c|}
\hline & $\begin{array}{l}\text { Exp. as } \\
\text { President }\end{array}$ & $\begin{array}{l}\text { Admin. } \\
\text { Experience }\end{array}$ & $\begin{array}{l}\text { Linked/Unlinked } \\
\text { Institution }\end{array}$ & $\begin{array}{l}\text { Highest } \\
\text { Degree } \\
\text { Earned }\end{array}$ & $\begin{array}{l}\text { Degree } \\
\text { Field }\end{array}$ & \multicolumn{2}{|c|}{ Age Gender } \\
\hline $\begin{array}{l}\text { Leadership } \\
\text { and } \\
\text { Governance .59 }\end{array}$ & & -.18 & .58 & -.15 & .66 & 1.10 & -.29 \\
\hline $\begin{array}{l}\text { Organizational } \\
\text { Structure and } \\
\text { Staffing } 1.28\end{array}$ & & .09 & .87 & -.88 & .29 & 1.16 & .04 \\
\hline $\begin{array}{l}\text { Organizational } \\
\text { Culture } 1.12\end{array}$ & & -.74 & .79 & -1.12 & .09 & .73 & -.47 \\
\hline $\begin{array}{l}\text { Resources and } \\
\text { Funding } 1.23\end{array}$ & & -.28 & .93 & -.95 & .39 & 1.06 &.-28 \\
\hline $\begin{array}{l}\text { Information } \\
\text { and Data }\end{array}$ & 1.12 & -.20 & .43 & -.85 & .76 & 1.33 & .01 \\
\hline $\begin{array}{l}\text { Relationship } \\
\text { Building 1.15 }\end{array}$ & & -.55 & 1.14 & -.86 & .25 & .75 & -.65 \\
\hline Partnerships 1.07 & & -.49 & .99 & -.83 & .44 & 1.02 & -.49 \\
\hline Total Scale & 1.15 & -.36 & .87 & -.87 & .50 & 1.09 & -.32 \\
\hline
\end{tabular}




\section{Experience as President}

The first demographic question was, "How long have you served as President and/or CEO of your current community and technical college?" Those presidents with more experience $(\mathrm{M}=4.4, \mathrm{SD}=.3, \mathrm{~d}=1.15)$ were more likely to rate themselves higher with regard to the seven dimensions of college life which support labor market responsiveness.

\section{Experience as Administrator}

The second demographic question was "What are your total years of experience as an administrator in a community and technical college?" Those presidents with more experience as administrators $(\mathrm{M}=19.3, \mathrm{SD}=.9, d=-.36)$ were more likely to rate themselves lower with regard to the seven dimensions which support labor market responsiveness.

\section{Administratively Linked or Free Standing}

The third demographic question was "Is your community and technical college administratively linked to another institution?" Six $(60 \%)$ of the community and technical colleges were administratively linked to baccalaureate institutions. Those presidents whose institutions were not administratively linked to another institution (or free standing) tended to rate their institutions more highly with regard to the seven dimensions which support labor market responsiveness $(d=.87)$.

\section{Highest Degree Earned}

The next demographic question was "What is your highest degree earned?" Five (50\%) of the presidents reported an Ed.D. as their highest degree earned. Two (20\%) of the presidents reported a Ph.D. and three (30\%) reported an M.A. as their highest degree earned. The 
presidents with an Ed.D. and the presidents with a Ph.D. were combined to calculate a new mean. This combined mean and the mean for the presidents with an M.A. were used to calculate Cohen's $d$. There was a negative relationship between the highest degree earned and the seven dimensions of college life which support labor market responsiveness meaning that those presidents with advanced degrees rated their institutions lower with regard to the seven dimensions.

\section{Degree Field}

The participants were asked to identify the field of their highest degree. Of the ten presidents, seven (70\%) reported education as their highest degree earned. Three (30\%) reported a field other than education. These three fields included English, Philosophy, and Journalism. Those presidents who had a degree in an education field tended to rate their institutions slightly higher than those presidents who had a degree in a field other that education $(d=.50)$.

Age

Presidents were asked to select an age range in response to this question. The ranges are found in Appendix B. Out of the 10 presidents, 3 reported an age range of 45-55, and 7 reported an age range of 56-65. Those presidents who reported an age range of 56-65 rated their institutions more highly with regard to implementing the seven dimensions $(d=1.09)$.

\section{Gender}

The presidents were asked to identify their gender. There were seven male presidents and three female presidents. Negative $d$ values indicated that the females rated their institutions slightly higher in implementing the seven dimensions of labor market responsiveness $(d=-.32)$. 
In summary, experience as a president, an administratively linked or unlinked institution, the highest degree earned, and age had a large effect size. Administrative experience, degree field, and gender had a medium effect size. 


\section{CHAPTER 5: SUMMARY, CONCLUSIONS, AND RECOMMENDATIONS}

The previous chapters outlined the research problem, reviewed the relevant literature, presented the research method and procedures, and reported the results of the research. This chapter presents a summary of the study, discussion and conclusions drawn from the data and literature, and recommendations for further research.

\section{Summary}

Community colleges link student goals of productive employment and careers to economic and workforce development goals of having workers with the knowledge and skills to build and sustain flourishing economies. The linkage between community colleges and their local labor markets is at the heart of the community college mission. Labor market responsive community colleges deliver training and educational programs that address labor market needs and support economic sustainability and competitiveness.

In 2004, the U.S. Department of Education, Office of Vocational and Adult Education, sponsored the Community College Labor Market Responsiveness Initiative. Within this effort, the U.S. Department of Education studied labor market responsiveness at 30 community colleges nationwide. They identified seven common characteristics of college life shared among these labor market responsive community colleges. These seven dimensions are: (a) leadership and governance; (b) organizational structure and staffing; (c) organizational culture; (d) resources and funding; (e) information and data; (f) relationship building and (g) partnerships.

The researcher set out to determine the extent to which the Presidents of the ten public community and technical colleges in the state of West Virginia perceived their institutions implementing these seven dimensions of college life in support of labor market responsiveness. 
Additionally, the researcher attempted to determine whether the institutional factors of institution size based on 2007 student FTE, number of counties in the institutional service area, and the 2007 annual operating budget were related to the presidents' perceptions regarding the seven dimensions. Finally, the researcher attempted to determine if there was a relationship between the presidents' demographics and the seven dimensions of college life that support labor market responsiveness.

This study was limited to 10 participants. These 10 participants represent all of the presidents of each public community and technical college in the state of West Virginia. The small sample limits the applicability of inferential statistics. The correlational nature of the data was survey based, and there was no attempt to address the causes of the relationships shown in the study. All ten presidents of each West Virginia public community and technical college completed an on-line survey (resulting in a response rate of $100 \%$ ). The data were analyzed using descriptive statistics, Cronbach's alpha coefficient, the Spearman correlation coefficient, and Cohen's $d$.

The researcher found that in answer to the questions in chapter 1 the presidents did not rate their institutions equally on their ability to implement the seven dimensions of college life that support labor market responsiveness. Furthermore, the researcher found that there were measurable relationships between these seven dimensions and the three variables of institution size based on student FTE, number of counties in the institutional service area, and the annual operating budget. Finally, there were measurable relationships regarding the demographics of the presidents and the seven dimensions. In the next section of this chapter, the data is looked at question by question. 


\section{Research Questions}

Question 1: What is the extent to which the West Virginia community and technical college presidents perceive their institutions as exhibiting leadership and governance?

The presidents rated 10 statements regarding leadership and governance. Two out of the 10 statements under the leadership and governance category shared the highest mean. These were statements number 2; labor market responsiveness is reflected in the college mission statements, and statement number 6 ; leaders portray the college as an economic development partner to the community. The mean for these statements was $4.4(\mathrm{SD}=.6)$.

It is of interest that $90 \%$ of the presidents rated these two statements as "almost always" or "completely." This finding was aligned with the suggestion in the literature that the leadership of a community college needs to be committed to the development and growth of a market-responsive approach. Labor market responsive community colleges incorporate workforce and economic development as an institutional commitment. The literature stresses that one of the ways that leadership can demonstrate commitment to labor market responsiveness is to identify it as part of the college's mission (Bailey \& Averianova, 1998; Carnevale, 2000; Warford \& Flynn, 2002).

The statement with the lowest mean $(\mathrm{M}=3.7, \mathrm{SD}=.8)$ was number 5; leaders maintain a vision beyond the traditional service area. Although this was the lowest mean, it was consistent with the expectations described in Chapter 2 regarding the passage of Senate Bill 448. This Senate Bill defined consortia planning districts or service areas for each of the ten community and technical colleges in West Virginia. Therefore, presidents are not encouraged, as defined in state code, to reach out beyond their service areas. 
The Spearman's correlation coefficient indicated that there was a strong positive relationship between an institution's student FTE and an institution's annual operating budget. Expanding beyond a community and technical college's defined service area may create a competitive environment because it may appear that one institution is increasing student FTE at the expense of another institution.

Cohen's $d$ showed that there was a higher effect when presidents with more years of experience were compared to presidents with fewer years of experience. This indicates that presidents, who have served longer in their roles, evaluated their institutions more highly with regard to leadership and governance. This finding was consistent with the literature that the most significant internal influence on community college governance is the formal organization with the president at its center (Vaughan, 2006).

Question 2: What is the extent to which the West Virginia community and technical college presidents perceive their institutions as having appropriate organizational structures and staffing?

Within the 7 statements rated regarding organizational structure and staffing, $100 \%$ of the Presidents responded either "almost always" or "completely" to the statement "the college's organizational chart and staffing structure reflect the equal importance of credit and noncredit programs." In addition, the most consistency was found in this particular statement $(\mathrm{M}=4.2$, $\mathrm{SD}=.4)$. These results were supported in the literature's explanations that labor market responsive community colleges build bridges across the traditional credit-noncredit divide and that much of the curricula developed for noncredit courses can benefit students in credit programs.

The last statement regarding organizational structure and staffing, "program development, outreach, and interaction are considered everyone's job," had the highest mean 
$(\mathrm{M}=4.3, \mathrm{SD}=.9)$. Sixty percent of the presidents rated this statement as "completely."

Presidents with more experience tended to rate organizational structure and staffing higher than the other 6 dimensions of college life.

It is interesting to note that the presidents with higher institutional annual operating budgets evaluated their institutions lower with regard to organizational structure and staffing. It is possible that these institutions have workforce development divisions embedded deep within their organizational structures. Fifty percent of the presidents indicated "almost always" to statement 6; human resources are deployed in the most efficient manner to meet labor-market responsive goals. This statement had the lowest mean $(\mathrm{M}=3.4, \mathrm{SD}=.6)$. It may appear that while the presidents perceive program development, outreach, and interaction as everyone's responsibility, the institutions may not have adequate funding to hire or contract personnel needed to expand labor market responsive capabilities.

Question 3: What is the extent to which the West Virginia community and technical college presidents perceive their institutions as exhibiting supportive organizational culture?

The data showed that the most consistency $(\mathrm{M}=4.2, \mathrm{SD}=.6)$ within the 7 statements regarding organizational culture appeared in statement 3; leaders and staff are open to change, committed to serving students and employers, and respectful of workplace culture. Ninety percent of the presidents responded to this statement as "almost always" or "completely." In addition to perceiving their institutions favorably with regard to service and culture, $90 \%$ of the presidents perceived their institutions as having a willingness to work closely with representatives from business and industry in the design, development, and delivery of education and training. The literature describes a labor market responsive college as one where faculty 
and staff work together to respond to diverse cultures and changing student populations. New attitudes prevail over traditional mindsets (MacAllum et al. 2004).

It is of interest that the lowest mean $(M=3.8, S D=.7)$ was found in statement 7; college leaders, faculty, and staff share a common understanding of the proper balance of the college's multiple missions. In addition, the presidents with high student FTE counts evaluated their institutions lower with regard to organizational culture. The multiple missions of community colleges often create tensions on campus that surface in the organization's culture. The realities of the world of work are changing. Community colleges have historically played a major role in preparing students to attend four-year postsecondary institutions. As evidenced by its legislative history, the ten public community and technical colleges in West Virginia have seen their mission shift from the single focus of transfer to a multiple focus which includes preparing students for workplace readiness. Faculty and staff from all divisions must work together to develop and deliver services and curriculum to meet labor market needs. Such collaborative endeavors expand the capabilities of the community college (Drury, 2001; Pindar, 1999; Seppanen, 1991).

Question 4: What is the extent to which the West Virginia community and technical college presidents perceive their institution's allocation of resources and funding to be sufficient?

The data indicated that there was a strong positive relationship between the community college's annual operating budgets and institutional size as measured in student FTE. This is perhaps because the funding formula for determining a state allocation is largely based on a student FTE count.

Eighty percent of the presidents responded either "almost always" or "completely" to statement number 8 regarding resources and funding; the college president, board members, and 
top administrators are personally invested in developing large-scale partnerships that fund responsive programs. This particular statement had the highest mean $(\mathrm{M}=4.2, \mathrm{SD}=.7)$ compared to the other 9 statements within the category of resources and funding. This finding was supported by the literature's suggestion that building financial capacity is an essential building block in achieving the college's mission (Myran, 2003).

West Virginia provides state funded competitive grant opportunities for its public community and technical colleges. This funding is beyond the annual state allocation or budget received by each of the 10 public community and technical colleges in West Virginia. These grants require evidence of partnerships with local employers.

The data indicated that while the presidents perceived their institutions favorably regarding the commitment to develop partnerships that fund responsive programs, the data also indicated that the presidents did not perceive their institutions equally demonstrating the ability to secure strong financial support from local sources. Statement number 6 , "the college is successful in securing strong financial support from local sources," had the least consistency (M $=3.6, \mathrm{SD}=1.3)$. Sixty percent of the presidents responded "almost always" or "completely" to this statement. It could be that institutional annual operating budgets and grant opportunities are largely established from state revenues and that obtaining financial support from local sources is a challenge.

Statement number 10, "adequate resources are invested in the professional development of faculty and staff to enable them to effectively implement responsive programs," shared a low mean with other statements $(\mathrm{M}=3.6, \mathrm{SD}=.6)$. Ninety percent of the presidents chose "somewhat" or "almost always" in response to this statement. This may indicate that although there is interest in providing adequate resources for professional development that supports labor 
market responsiveness, inadequate annual budgets at the community and technical colleges in West Virginia may prohibit campus leaders from allocating sufficient funding. This finding was apparently in conflict with the literature which indicates that professional development is necessary in order to create and sustain a culture of labor market responsiveness (MacAllum et al. 2004).

Question 5: What is the extent to which the West Virginia community and technical college presidents perceive their institutions as utilizing information and data?

The data showed that presidents with higher student FTE counts and higher institutional annual operating budgets evaluated their institutions lower with regard to utilizing information and data. The data reflected that the presidents rated their institutions lowest in the category of information and data (Cronbach's alpha $=.91)$. In addition, the data showed that six of the ten West Virginia public community and technical colleges were administratively linked to four-year institutions. Senate Bill 448 provided the public community and technical colleges in West Virginia with the authority to develop administrative autonomy. It could be that these administratively linked institutions did not yet have direct responsibility for their information and data.

Fifty percent of the presidents responded "somewhat" to statement number 7; “anticipatory thinking, based on solid information and data, pervades campus culture, informs outreach to partners, and shapes future vision." This statement had the lowest mean $(\mathrm{M}=3.4$, $\mathrm{SD}=.8$ ). Obtaining information and data for decision making and strategic planning is a theme that runs through the literature. Community colleges rely on information and data to determine which programs may no longer be relevant to the workforce and which programs support employers' current and emerging workforce needs. Community colleges that successfully train 
students in highly sought-after skills become attractive as training resources to local businesses (Salter, 1999; Seppanen, 1991).

Overall, the presidents perceived their institutions as engaged in utilizing information and data as evidenced by their responses to statements 3,5 , and 6 . It is noteworthy to acknowledge that statement number 6, "the college evaluates the satisfaction of local businesses, partners, students, and their employers," had the least consistency $(\mathrm{M}=3.8, \mathrm{SD}=1.3)$. It appeared that some presidents perceived that their institutions are not implementing this dimension of labor market responsiveness.

Question 6: What is the extent to which the West Virginia community and technical college presidents perceive their institutions as building relationships with their relevant constituencies?

Ninety percent of the presidents responded as "almost always" or "completely" to the statements which included developing relationships with a variety of local organizations, seeking new ways to market itself, and recognizing strategic relationship building as the foundation for establishing strategic partnerships. Fifty percent of the presidents selected "completely" as a response to statement 5; "the trustees and president communicate the college's mission of labor market responsiveness in the public eye and in circles of influence."

Statement number 7, "marketing activities encourage others to approach the college as a partner," had the lowest mean of all the statements within the relationship building category (M $=3.6, \mathrm{SD}=.6$ ). According to the literature, mission statements and strategic plans help promote the message that a community college is a responsive and flexible economic development partner (MacAllum et al. 2004). Possibly, the perception that marketing activities do not always position the community college as a partner may be related to more than an institution's budget. Marketing is more than paid advertising. It is possible that this perception is related to an 
institution's culture. Labor market responsive community colleges realize that it is the responsibility of everyone, including faculty and administrators to play an active role in reaching out to the community. Mission and vision statements, strategic plans, and college team members help to promote the message that a community college is a responsive and flexible economic development partner (MacAllum et al. 2004).

The statement with the least consistency $(\mathrm{M}=4.0, \mathrm{SD}=1.1)$ was statement number 4, "relationship building is recognized as everyone's job." Eighty percent of the presidents responded either "almost always" or "completely" to this statement. It is interesting to note that 2 of the presidents evaluated their institutions as "slightly" with regards to this statement. Both of these presidents served in their positions at community and technical colleges which were linked to 4 year baccalaureate institutions. It may be that these 2 community and technical colleges operated within an organizational structure that does not encourage a team approach in regards to responsibility for building relationships. Historically, the public community and technical colleges in West Virginia were established with an emphasis on a transfer mission. It may be possible that these 2 presidents perceived their institutions as operating within a structure and a culture that did not fully support this dimension of labor market responsiveness.

Question 7: What is the extent to which the West Virginia community and technical college presidents perceive their institutions as establishing partnerships with local employers and economic development agencies?

Out of the 7 statements rated in this category, the statements 1 and 5 had the highest mean. Statement 1, "the college is engaged in sustained, successful employer partnerships that are responsive to the local market," had a mean of $3.9(\mathrm{SD}=4.0)$. Statement 5, "the college partners with large employers and innovative industries," had a mean of $3.9(\mathrm{SD}=1.1)$. The 
literature stresses that businesses find partnerships with community colleges attractive because community colleges can develop and deliver complex and long-term training (National Alliance of Business, Inc., 2001).

Fifty percent of the presidents responded "almost always" or "completely" to statement 7, "partnerships are assessed and maintained in proportion to the ability to leverage long-term outcomes and opportunities $(\mathrm{M}=3.3, \mathrm{SD}=1.1)$. The data indicated that the presidents with higher student FTE counts and higher institutional annual operating budgets evaluated their institutions lower with regard to establishing partnerships with local employers and economic development agencies.

According to the literature, presidents and board members play important roles in building partnerships with businesses and economic development agencies. Leveraging for the future rather than for short-term gain is a common feature of a successful partnership. In addition, community colleges bring to the table the ability to develop customized training and degrees that are critically important in local and regional economic development initiatives (MacAllum et al. 2004).

It may be possible that given the defined service areas for each community college, these institutions were not reaching beyond the traditional student populations they served in an effort to build capacity to meet emerging workforce training needs. Long-term partnerships with employers require flexibility. Perhaps the institutions with higher student FTE count and larger annual operating budgets were more focused on a transfer mission rather than a workforce development mission.

Statement 6, "the college encourages and rewards its staff for entrepreneurial activity," had the least consistency of all of the statements $(\mathrm{M}=3.4, \mathrm{SD}=1.2)$. This response may be 
related to the compensation restrictions that are inherent in the personnel policies of the community and technical college system of West Virginia.

Question 8: Is there a relationship between the extent to which the presidents perceive their $\underline{\text { institutions as implementing the seven dimensions of college life support labor market }}$ responsiveness and the institutional factors of (a) size of institution based on student FTE, (b) number of counties in the service area, and (c) annual operating budget?

The responses of the presidents revealed some answers as to the relationship between the institutional demographics and the perceptions of the presidents. The data showed that the number of counties in an institution's defined service area or planning consortium had a small relationship with regard to the 2007 student FTE headcount. The researcher concludes that the relationships are small and that they are not greatly related to the presidents' perceptions of how their institutions implement the seven dimensions of college life in support of labor market responsiveness.

The data showed a small relationship with regard to the number of counties in an institution's defined service area with regard to an institution's 2007 annual operating budget. However, the data showed a strong positive relationship between an institution's annual operating budget and student FTE $\left(\mathrm{r}_{\mathrm{s}}{ }^{2}=.88\right)$. The presidents with higher 2007 annual operating budgets and higher 2007 student FTE headcount tended to rate their institutions lower with regard to their institutions implementing the seven dimensions of college life in support of labor market responsiveness. These institutions may have organizational structures that serve the traditional roles in the transfer mission. According to the literature, substantial enrollments and budgets indicate that there are appropriate administrative resources to devote to designing labor market-responsive programs and the resources to develop cooperative programs with businesses 
and economic development groups (MacAllum et al. 2004). The early public and community technical colleges in West Virginia were established as branch campuses with an emphasis on transfer programs. It is possible that the institutions with larger 2007 annual operating budgets and larger 2007 student FTE headcount continue to focus primarily on this facet of the community college mission.

The amount of an institution's budget may be related to the length of time that the community and technical college has been established. The data showed that $50 \%$ of the 10 public community and technical colleges established in 1974 or before have state budget allocations greater than 5 million dollars. According to the literature, the State Legislature passed legislation in 1961 that allowed the establishment of 2 year branch colleges which would offer liberal arts, terminal education, and adult education (Plan for Comprehensive Community College Education in West Virginia, 1971).

It is possible that an institution that has been in existence for more years has had the opportunity to increase its state allocated budget. In addition, the longer an institution has been in existence, the more likely it is to have been formed as a component institution and be administratively linked to a Baccalaureate institution. This could create an institutional focus on transfer mission rather than on workforce and economic development.

Question 9: Is there a relationship between the extent to which the presidents perceive their institutions implementing the seven dimensions of labor market responsiveness and the presidents' demographics?

The responses of the presidents suggested that there was a large effect size with regard to experience as a president, an administratively linked or unlinked institution, highest degree 
earned and age. There was a medium effect size with regard to experience as an administrator, degree field and gender.

It may be that presidents with greater experience are more attuned to the importance of implementing dimensions that support labor market responsiveness. It is likely that a president with more experience is older. The data showed that the average length of time spent serving as a president was 4.2 years $(\mathrm{SD}=.4)$ and that the presidents' average for experience as an administrator in a community and technical college was $19.25(\mathrm{SD}=.5)$. These findings are supported by the literature. According to Zeiss (2003), "aspiring community college presidents generally have worked about 25 years in their field, have earned a terminal degree, and have changed colleges two or three times to obtain the experience needed to even be considered for the position" (p. 121). Zeiss (2003) also states that the average community college president holds the office for approximately 5 years.

Presidents who responded that their institutions were not administratively linked to a four-year institution rated their institutions more highly with regard to the seven dimensions. It may be possible that these independent institutions have more control over dimensions such as organizational structure, culture, and information and data. It is possible that the independent institutions embrace and balance the multiple roles of a community college which include workforce and economic development. The literature clearly points out that community colleges have historically pursued multiple missions yet their emergence as trainers of choice has positioned them as engines of workforce and economic development, improving the economy of their communities and simultaneously improving the employment opportunities of their students (MacAllum et al. 2004). 


\section{Conclusions}

This study has revealed that the presidents of the ten public community and technical colleges in the state of West Virginia perceived their institutions as implementing all seven of the dimensions of college life which support labor market responsiveness. The data suggest that the presidents did not perceive their institutions implementing all the dimensions equally. In addition, the data suggested that the presidents did not perceive a single dimension being uniformly implemented among the institutions.

There is an implication that size of a community and technical college's budget is related to the size of the institutional student FTE count. The presidents whose institutions were larger in terms of annual operating budget and student FTE count perceived four dimensions as challenges: (a) organizational structure and staffing; (b) organizational culture; (c) information and data; and (d) partnerships.

According to the literature, the public community technical colleges developed early in West Virginia. The first were established as branch campuses with an emphasis on transfer programs. Prior to 2004, the public community and technical colleges were considered Associate degree granting institutions which were considered as components and administratively linked to Baccalaureate degree institutions. Before Senate Bill 2004, the community and technical colleges' organizational structure was tightly woven within the Baccalaureate host institutions. Given the history of the West Virginia community and technical colleges, it is possible that the institutions with larger 2007 annual operating budgets and larger 2007 student FTE headcount continue to focus primarily on the transfer role of the community college mission. 
There was one president who rated the seven dimensions of college life below the mean compared to the other presidents. Analyzing the demographic characteristics of the group compared to this president, the researcher found that a possible explanation for this president's ratings may be that this participant was a new and first-time president at an administratively linked institution.

\section{Implications}

The public community and technical colleges in this study have focused their mission primarily on providing access to higher education to West Virginia citizens and on developing the workforce skills of these citizens in order to compete in a global economy. Based on the findings of this study, the researcher proposes the following implications:

1. The president and the community and technical college's board are the primary catalysts for building financial capacity. The data indicated that the presidents did not perceive their institutions equally demonstrating the ability to secure strong financial support from local sources. In research question 4, statement number 6 had the least consistency. This statement, "the college is successful in securing strong financial support from local sources," had a mean of $3.6(\mathrm{SD}=1.3)$. In order to build financial capacity, the president and the board of each institution may need to emphasize seeking funding from other than state sources such as federal grants, partnerships with local business, and the development of foundations.

2. Professional development activities could be developed to address the importance of the seven characteristics of labor market responsiveness and help faculty and 
staff succeed in the new roles of outreach and interaction with local business and industry. Ninety percent of the presidents responded "somewhat" or "almost always" to statement number 10 in research question 4 . This statement was "adequate resources are invested in the professional development of faculty and staff to enable them to effectively implement responsive programs." The literature indicated that professional development was important in order to build a culture of labor market responsiveness. An institution may consider establishing or encouraging an existing professional development committee to create learning opportunities that support labor market responsive efforts.

3. Community and technical college presidents could establish ways to recognize and reward staff and faculty for work which supports labor market responsiveness. In research question 7 , statement 6 had the least consistency. This statement, "the college encourages and rewards its staff for entrepreneurial activity" had a mean of $3.4(\mathrm{SD}=1.2)$. Rewards and recognition, appropriate to each institution, could be creatively developed by small task forces.

4. Community and technical colleges have little control over their state funded annual operating budgets. The data indicated that the presidents did not perceive their institution's allocation of resources and funding to be sufficient. Building positive partnerships with local employers, other community colleges, chambers of commerce, and economic development agencies may improve the community and technical colleges' position when seeking state financial support. 
5. Community and technical colleges rely on information and data in order to plan effectively and make decisions. The community and technical colleges with the largest size in student FTE and budget allocation rated their institutions lower in utilizing information and data. Community colleges have the greatest degree of control over internally developed data. The community and technical colleges may seek to identify the different types of internal and external data critical to decision making and planning and determine ways of gaining greater access to this data.

\section{Recommendations for Further Research}

Based on the findings of this study, future studies which continue to explore labor-market responsive community colleges could incorporate the following recommendations:

1. The sample size of this study was limited to ten participants. The public community and technical colleges in West Virginia may not be typical of other community and technical colleges in different states. It is recommended that this study be replicated with community college systems in other states, and that this study be replicated with a sample from a larger population. Greater generalization of results may be possible from a study that involves a larger population.

2. This study was conducted during a time of slowing economic conditions. Future studies similar to this one could be conducted to determine whether or not the presidents of community and technical colleges have changed their perceptions regarding the seven dimensions of labor market responsiveness. 
3. Other target populations distinct from the presidents of the public community and technical colleges in West Virginia could be analyzed to determine what similarities and differences exist. These populations could include faculty, classified staff, non-classified staff, and governing boards.

4. Future studies could include a look at relationships between different institutional factors such as total operating revenue or per student expenditure which would include a state allocation, and tuition and fees and the seven characteristics of labor market responsiveness (for example, the relationship between staff size and the implementation of the seven dimensions or the relationship between geographic locations and the seven dimensions).

5. Similar studies could be conducted utilizing a mixed methods approach which would include qualitative as well as quantitative methods such as a follow-up interview with presidents or other participants.

6. A similar study could be conducted that incorporates the West Virginia public community and technical colleges' performance standards and the seven dimensions of college life which support labor market responsiveness. 


\section{REFERENCES}

Ali, A. (2007, April 27). Evolving education: Community and technical colleges find their place in teaching West Virginians. The State Journal, p 1.

American Association of Community Colleges (2004). Linking Training to Performance.

Washington, DC: American Association of Community Colleges.

American Association of Community Colleges (2004). Effective teaching: A guide for community college instructors. Washington, DC: American Association of Community Colleges.

American Association of Community Colleges (1997). Core Issues in Community Colleges. Washington, DC: American Association of Community Colleges.

Ashburn, E. (2006, October 27). Listening to the business community. The Chronicle of Higher Education, p. B3.

Bailey, T.R. \& Averianova, I. E. (1998). Multiple missions of community colleges: conflicting or complementary? Community College Research Center, Teachers College, Columbia University.

Bailey, T.R. \& Morest, V. S. (2004). The organizational efficiency of multiple missions for community colleges. Community College Research Center, Teachers College, Columbia.

Bogart, Q.J. (1994). The community college mission. In G.A. Baker (ed.). A handbook on the community college in America (pp, 60-73). Westport, CT: Greenwood Press.

Brand, B. (1997). Community colleges and economic development. Waco, TX: The Center for Research and Development. 
Brewer, D. \& Gray, M. (1997). Connecting colleges and community in the new economy. Washington, DC: U.S. Department of Education, Office of Adult and Vocational Education. (ERIC Document Reproduction Service No. ED411033)

Cantor, J.A. (2002). Skills certification and workforce development: Partnering with industry and ourselves. Leadership Abstract. The League for Innovation. (ERIC Document Reproduction Service No. ED481380)

Carnegie Foundation for the Advancement of Teaching. (1989). Building for a new century: Higher education in West Virginia. Charleston, WV: Sarah and Pauline Maier Foundation, Inc.

Carnevale, A.P. \& Desroches, D. M. (2001). Help wanted...credentials required. Community colleges in the knowledge economy. Princeton, NJ: Educational Testing Services. Carnevale, A.P. (2000). Community colleges and career qualifications. New Expeditions: Charting the second century of community colleges. (Issues Paper No. 11). Annandale, VA: American Association of Community College Trustees. (ERIC Document Reproduction Service No. ED439743)

Chancellor's Office. (1996). Maximizing Your Impact in Contract Education. California Community Colleges, Sacramento.

Cohen, A.M. \& Brawer, F. (1996). The American community college ( $3^{\text {rd }}$ ed.). San Francisco: Jossey-Bass Inc., Publishers.

Coley, R.J. (2000). The American community college turns 100: A look at its students, programs, and prospects. Princeton, NJ: Educational Testing Service, Policy Inform ation Center. 
Dougherty, K. \& Bakia, M.F. (2000). Community colleges and contract training: Content, origins, and impact [Electronic version]. Teachers College Record, 102, (1), 197-243.

Dougherty, K. \& Bakia, M.F. (1999). The new economic development role of the community college. Community College Research Center, Teachers College, Columbia University.

Drury, R. L. (2001). The entrepreneurial community college: Bringing workforce, economic and community development to Virginia communities. Inquiry, 6, (1).

Flynn, W. J. (2005). Eight strategic questions for community colleges [Special issue]. Sungard SCT-Higher Education \& National Council for Continuing Education and Training.

Gay, L.R. \& Airasian, P. (2003). Educational research: Competencies for analysis and applications ( $7^{\text {th }}$ ed.). Upper Saddle River, NJ: Pearson Education, Inc.

Gravetter, F.J. \& Wallnau, L.B. (2004). Statistics for the behavioral sciences $\left(7^{\text {th }}\right.$ ed.). Belmont, CA: Wadsworth/Thomson Learning.

Gunderson, S. (2005). New Directions for Workforce Development. Community College Journal, 54-55.

Grubb, W., Badway, N., Bell, D., Bragg, D. \& Russman, M. (1997). Workforce, economic, and community development: The changing landscape of the entrepreneurial community college. University of California at Berkeley. Berkeley, CA: National Center for Research in Vocational Education. (ERIC Document Reproduction Service No. ED413033)

Gruber, D. (2000) We're education...you're semiconductors. Working Ventures. Philadelphia, PA: Public/Private Ventures. (ERIC Document Reproduction Service No. ED438463) Harmon, R., \& MacAllum, K. (2003). Documented characteristics of labor market-responsive community colleges and a review of supporting literature. Washington, DC: U.S. 
Department of Education, Office of Adult and Vocational Education.

Hirshberg. D. (1991). The role of the community college in economic and workforce development. ERIC Clearinghouse for Junior Colleges, Los Angeles, CA. (ERIC Docum ent Reproduction Service No. ED339443)

Hickman, R.C., \& Quinley, J.W. (1997, May). A synthesis of local, state, and national studies in workforce education and training. Paper presented at the Annual Forum of the Association of Institution Research, Orlando, FL.

Katsinas, S.G. \& Lacey, V.A. (1989). Community colleges and economic development: Models of institutional effectiveness. Washington, DC: American Association of Community Colleges.

Kisner, M. J., Mazza, M. J. \& Liggit, D. R. (1997). Building Partnerships. New Directions for Community Colleges, 25 (1), 23-28.

Liebowitz, M., Haynes, L. \& Milley, J. (2001). Driving change in community colleges, Volume 1: Building systems for advancement to self sufficiency, Volume 2: An analysis of changes in two community colleges. Boston, MA: Jobs for the Future. (ERIC Document Reproduction Service No. ED457894)

Likert, R. (1932). A Technique for the Measurement of Attitudes. (Archives of Psychology R.S. Woodworth, editor, No. 140) New York: New York University.

Lynch, R., Palmer, J.C., \& Brubb, W.N. (1991). Community college involvement in contract training and other economic development activities. Report for the Office of Vocational and Adult Education. Berkeley, CA: National Center for Research in Vocational

Education.

MacAllum.K., Yoder.K., \& Poliakoff, A. (2004). Unleashing the Power of the $21^{\text {st }}$ Century 
Community College: Maximizing Labor Market Responsiveness. Washington, DC:

Academy for Educational Development National Institute for Work and Learning.

McCall, M. (2005). Advocacy and an agenda for economic development: Community College Journal, 75 (6), 5-7.

Morgan, S., Reicher, T., \& Harrison, T. (2002). From Numbers of Words: Reporting Statistical Results for the Social Sciences. Boston, MA: Allyn \& Bacon.

Myran, G., Baker, G.A., Simone, B., \& Zeiss, T. (2003). Leadership strategies for community college executives. Washington, DC: American Association of Community Colleges.

National Alliance of Business, Inc. (2001). The future of worker training: Business/community college partnerships. Workforce Economics, 7 (1), 3-6.

Nespoli, L.A., Lam, L., \& Farbman, J. (2004). N.J.'s community college compact: A strategic blueprint for workforce development programs. Community College Journal, 74 (6), 26-28.

Ohio Board of Regents (2001). Information technology skills--Ohio employers' labor demand: Implications for EnterpriseOhio network campus-wide leadership. Kirtland, $\mathrm{OH}$ : EnterpriseOhio Network Professional Development Resource Center.

Ohio Board of Regents (2000). Business performance improvement: Examples of successful partnerships. Columbus OH: EnterpriseOhio Network Professional Development Resource Center.

Parnell, D. (1990). Dateline 2000: The new higher education agenda. Washington, DC: Community College Press.

Payne, J. H. \& Williams-Foster, C. (1997). Industry and education: A winning combination. Performance Improvement. 36 (1), 18-20. 
Phillippe, K. A. \& Sullivan, L. G. (2005). National profile of community colleges: Trends \& Statistics. Washington, DC: American Association of Community Colleges.

Pindar, S. (1999). Community colleges and the business of workforce development. Trenton, NJ: New Jersey Council of County Colleges. (ERIC Document Reproduction Service No. ED454935)

Roueche, J. E. \& Jones, B. R. (Eds.). (2005). The entrepreneurial community college. Washington, DC: Community College Press.

Roberts, B. (2002). The best of both [Electronic version]. Working Ventures. Philadelphia, PA: Public/Private Ventures.

Salter, L. (1999). Down in the valley. Community College Journal, 70 (2), 37-41.

Schwager, M. \& Lee, J. (2000). Industry review and validation of model curriculum for programmer/analyst, network administration, and technical support. San Francisco, CA: California Community Colleges, Office of the Chancellor. (ERIC Document Reproduction Service No. ED455400)

Seppanen, L. (1991). Assessment of meeting employer needs and the labor market experience of job upgrading and retraining students in Washington community colleges. A baseline report. (Report No. 91-3). Olympia, WA: Washington State Board of Community College Education. (ERIC Document Reproduction Service No. ED345790)

Strayer, G. D. (1945). A report of a survey of public higher education in the state of West Virginia. Legislative Committee, State of West Virginia (pp. 673-676).

Thompson, I. (1997, April). Silicon and ivy: Enhancing California's workforce and educational goals through the corporate college model. Materials presented to the California Community College Foundation, San Jose, California, CA. 
U.S. Department of Education, Office of Vocational and Adult Education. (2004). The $21^{\text {st }}$ Century Community College: A Strategic Guide to Maximizing Labor Market Responsiveness (Vols. 1-3). Washington, DC: U.S. Department of Education

Publications Center.

Vaughan, B.G. (2006). The community college story ( $3^{\text {rd }}$ ed.). Washington, DC: American Association of Community Colleges.

Warford, L.J., \& Flynn, W.J. (2000). New games new rules: Strategic positioning for workforce Developm ～ent. Community College Journal, 70 (7), 31-33.

West Virginia Board of Regents. (1971). A plan for comprehensive community college education in West Virginia.

West Virginia Board of Regents. (1970). Assessment of two-year college needs in West Virginia. West Virginia Committee on Higher Education. (1966). Higher education in West Virginia-A self assessment (Vol. I, pp. 33).

West Virginia Higher Education Advocacy Team. (1992, September). Report of the higher education advocacy team. Charleston, WV: West Virginia Higher Education Advocacy Team

Whiteman, J. M. (2001). Business curriculum development in the community college. University of Central Florida. (ERIC Document Reproduction Service No. ED455418) 


\section{APPENDIX A}

Table 4-19 WV Community and Technical Colleges Consortium District, and Inclusive Counties

\begin{tabular}{|c|c|c|}
\hline West Virginia Community and Technical College & Consortium district & Inclusive counties \\
\hline \multirow[t]{3}{*}{ Blue Ridge Community and Technical College She } & handoah & Berkeley \\
\hline & & Jefferson \\
\hline & & Morgan \\
\hline \multirow{5}{*}{$\begin{array}{l}\text { Community and Technical College at West } \\
\text { Virginia University Institute of Technology }\end{array}$} & Advantage Valley & Clay \\
\hline & Southeastern Fayette & \\
\hline & & Kanawha \\
\hline & & Nicholas \\
\hline & & Raleigh \\
\hline \multirow[t]{6}{*}{ Eastern Community and Technical College Potom } & ac Highlands & Grant \\
\hline & $\mathrm{Ha}$ & mpshire \\
\hline & & Hardy \\
\hline & & Mineral \\
\hline & & Pendleton \\
\hline & & Tucker \\
\hline \multirow[t]{4}{*}{ Marshall Community and Technical College } & Advantage Valley & Cabell \\
\hline & & Mason \\
\hline & & Putnam \\
\hline & & Wayne \\
\hline \multirow[t]{9}{*}{ New River Community and Technical College } & Southeastern & Fayette \\
\hline & & Greenbrier \\
\hline & & Mercer \\
\hline & & Monroe \\
\hline & & Nicholas \\
\hline & & Pocahontas \\
\hline & & Raleigh \\
\hline & & Summers \\
\hline & & Webster \\
\hline
\end{tabular}


Appendix A (continued)

Table 4-19 WV Community and Technical Colleges Consortium District, and Inclusive Counties

\begin{tabular}{lll}
\hline West Virginia Community and Technical College & Consortium district & Inclusive counties \\
\hline Pierpont Community and Technical College North & Central & Barbour \\
& Braxton \\
& Calhoun \\
& Doddridge \\
\hline
\end{tabular}


APPENDIX B

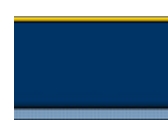

West VirginiaUniversity.

A-Z Site Index · Campus Map · Directory $\cdot$ WVU Calendar $\cdot$ WVU Home

Simpleforms

\section{Labor Market Responsiveness: Assessing Seven Dimensions of the West Virginia Community and Technical Colleges}

Please choose the most accurate response for each statement.

Leadership and Governance

\begin{tabular}{|c|c|c|c|c|c|}
\hline & Not at all & Slightly & Somewhat & $\begin{array}{l}\text { Almost } \\
\text { always }\end{array}$ & Completely \\
\hline $\begin{array}{l}\text { College leadership is shared among } \\
\text { multiple people. }\end{array}$ & 0 & 0 & 0 & 0 & 0 \\
\hline $\begin{array}{l}\text { Labor market responsiveness is } \\
\text { reflected in the college mission } \\
\text { statement. }\end{array}$ & 0 & 0 & 0 & 0 & 0 \\
\hline $\begin{array}{l}\text { Leaders, especially the board and } \\
\text { president, are fully and publicly } \\
\text { committed to a labor-market- } \\
\text { responsive mission. }\end{array}$ & 0 & 0 & 0 & 0 & 0 \\
\hline $\begin{array}{l}\text { Leaders are actively involved in } \\
\text { furthering that mission. }\end{array}$ & 0 & 0 & 0 & 0 & 0 \\
\hline $\begin{array}{l}\text { Leaders maintain a vision beyond the } \\
\text { traditional service area. }\end{array}$ & 0 & 0 & 0 & 0 & 0 \\
\hline $\begin{array}{l}\text { Leaders portray the college as an } \\
\text { economic development partner to the } \\
\text { community. }\end{array}$ & 0 & 0 & 0 & 0 & 0 \\
\hline $\begin{array}{l}\text { College leaders are very visible in the } \\
\text { community. }\end{array}$ & 0 & 0 & 0 & 0 & 0 \\
\hline $\begin{array}{l}\text { College leaders are well informed on } \\
\text { economic and workforce trends. }\end{array}$ & 0 & 0 & 0 & 0 & 0 \\
\hline $\begin{array}{l}\text { Leaders convey local market } \\
\text { information to the broader campus. }\end{array}$ & 0 & 0 & 0 & 0 & 0 \\
\hline $\begin{array}{l}\text { Leadership style is passionate, } \\
\text { innovative, anticipatory, and } \\
\text { entrepreneurial. }\end{array}$ & 0 & 0 & 0 & 0 & 0 \\
\hline Ianizational Structure and Staffing & & & & & \\
\hline & Not at all & Slightly & Somewhat & $\begin{array}{l}\text { Almost } \\
\text { always }\end{array}$ & Completely \\
\hline $\begin{array}{l}\text { The organizational chart and staffing } \\
\text { structure of the community college } \\
\text { reflect a commitment to labor-market- } \\
\text { responsive services and programs. }\end{array}$ & 0 & 0 & 0 & 0 & 0 \\
\hline $\begin{array}{l}\text { The college's organizational chart and } \\
\text { staffing structure reflect the equal } \\
\text { importance of credit and noncredit } \\
\text { programs. }\end{array}$ & 0 & 0 & 0 & 0 & 0 \\
\hline $\begin{array}{l}\text { Campus structure facilitates } \\
\text { communication and access to the } \\
\text { human and financial resources } \\
\text { essential for labor-market-responsive } \\
\text { activities. }\end{array}$ & 0 & 0 & 0 & 0 & 0 \\
\hline
\end{tabular}


Credit and noncredit programs and their faculties collaborate to develop and deliver career-oriented training.

Close working relationships between the credit and noncredit sides of the

college enhance the college's ability to provide labor-market-responsive programs.

Human resources are deployed in the most efficient manner to meet labormarket-responsive goals.

Program development, outreach, and interaction are considered everyone's job.

Organizational Culture

A strong belief system embraces labor
market responsiveness as a core
mission.
The college is characterized by
flexibility, innovation, collaboration,
and entrepreneurship.

The college has a motto or theme that focuses attention on the mission of workforce and economic

development.

Leaders and staff are open to change, committed to serving students and employers, and respectful of workplace culture.

Workforce development strategies reflect the cultures of the surrounding communities and specifically address local needs.

There is a willingness to work closely with representatives from business and industry in the design,

development, and delivery of education and training.

College leaders, faculty, and staff share a common understanding of the proper balance of the college's multiple missions.

Resources and Funding

The college aggressively pursues nonstate sources of income.

The widest possible range of funding streams has been explored.

The college is innovative in developing and embracing new methods to raise funds for high-demand programs.

The community college is creative in seeking new sources of income to finance workforce development.

$\begin{array}{ccccc}0 & 0 & 0 & 0 & 0 \\ 0 & 0 & 0 & 0 & 0 \\ 0 & 0 & 0 & 0 & 0 \\ 0 & 0 & 0 & 0 & 0\end{array}$

Not at all Slightly Somewhat $\begin{gathered}\text { Almost Completely } \\ \text { always }\end{gathered}$

0

$\mathrm{O}$

O

0

$\mathrm{O}$

O

$\mathrm{O}$

$\mathrm{O}$

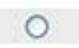

O

0

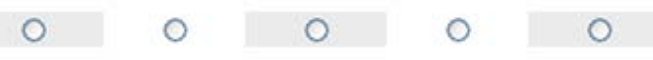

$\begin{array}{lllll}0 & 0 & 0 & 0 & 0\end{array}$

$\begin{array}{lllll}0 & 0 & 0 & 0 & 0\end{array}$ on

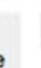

O

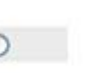

0

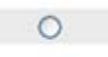

0

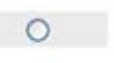

\begin{tabular}{|c|c|c|c|c|}
\hline & & & & \\
\hline 0 & 0 & 0 & 0 & 0 \\
\hline 0 & 0 & 0 & 0 & 0 \\
\hline 0 & 0 & 0 & 0 & 0 \\
\hline 0 & 0 & 0 & 0 & 0 \\
\hline 0 & 0 & 0 & 0 & 0 \\
\hline 0 & 0 & 0 & 0 & 0 \\
\hline 0 & 0 & 0 & 0 & 0 \\
\hline
\end{tabular}

\begin{tabular}{ccccc} 
Not at all & Slightly & Somewhat & $\begin{array}{c}\text { Almost } \\
\text { always }\end{array}$ & Completely \\
\hline & 0 & 0 & 0 & 0 \\
0 & 0 & 0 & 0 & 0 \\
0 & 0 & 0 & 0 & 0 \\
0 & & & & 0 \\
0 & & & 0 & 0
\end{tabular}




\begin{abstract}
College leadership is strategic in leveraging resources and in-kind donations to support and expand partnerships.

The college is successful in securing strong financial support from local

sources.

Sufficient human resources are dedicated to obtaining resources that support responsive programming and services.

The college president, board members, and top administrators are personally invested in developing

large-scale partnerships that fund responsive programs.

Discretionary resources are allocated equitably between academic and occupationally oriented programs.

Adequate resources are invested in the professional development of faculty and staff to enable them to

effectively implement responsive

programs.
\end{abstract}

Information and Data

The community college relies on local information-gathering and published

data to drive strategic planning for its responsive programs and services.

The college has cultivated a network of well-positioned leaders in the community to provide information about local needs and trends.

College leaders and staff are wellinformed about the needs of local

business and industry and future economic trends.

The college evaluates the impact of its market-responsive programs and services.

The college assesses the value of labor-market-responsive

programming and services and these assessments lead to programmatic change.

The college evaluates the satisfaction of local businesses, partners,

students, and their employers.

Anticipatory thinking, based on solid information and data, pervades campus culture, informs outreach to partners, and shapes future vision.

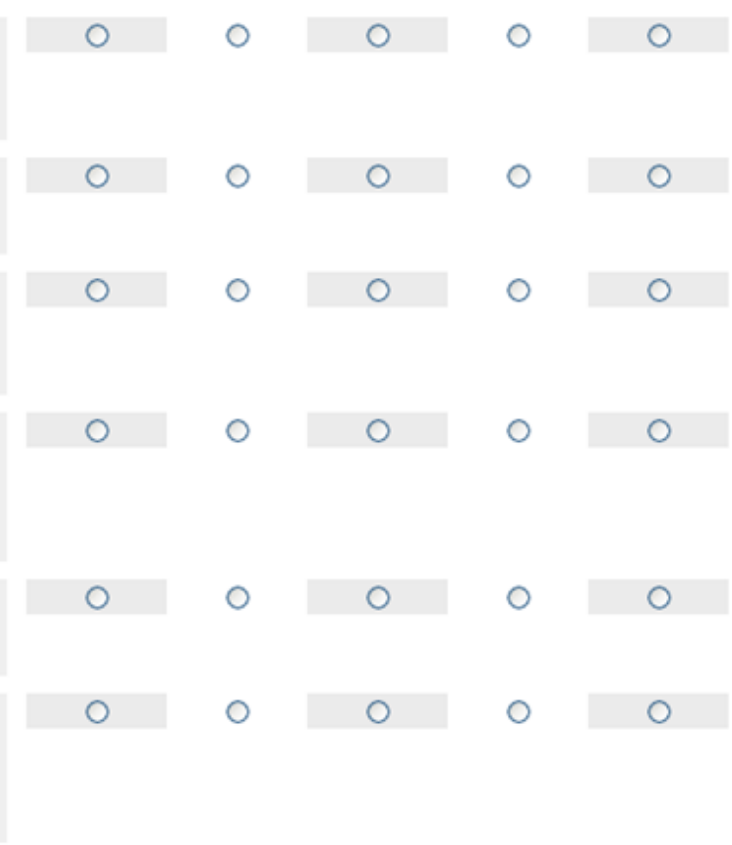

Not at all Slightly Somewhat Almost Completely always
$\mathrm{O}$
$\mathrm{O}$
0
O
O

O

O

0

O

O

0

O

0

O

O

O

O

O

O

O

O

O

0

O

O

0

0

0

0

0

O

0 


\begin{tabular}{|c|c|c|c|c|c|}
\hline & Not at all & Slightly & Somewhat & $\begin{array}{l}\text { Almost } \\
\text { always }\end{array}$ & Completely \\
\hline $\begin{array}{l}\text { The college reaches out to students, } \\
\text { businesses, and other organizations to } \\
\text { gather information about general } \\
\text { economic conditions and specific } \\
\text { employer concerns. }\end{array}$ & 0 & 0 & 0 & 0 & 0 \\
\hline $\begin{array}{l}\text { The college develops relationships } \\
\text { with a wide variety of local } \\
\text { organizations that could strengthen its } \\
\text { ability to be responsive. }\end{array}$ & 0 & 0 & 0 & $\mathrm{O}$ & 0 \\
\hline $\begin{array}{l}\text { Leaders and staff take an active and } \\
\text { aggressive stance in reaching out to } \\
\text { the community. }\end{array}$ & 0 & 0 & 0 & 0 & 0 \\
\hline $\begin{array}{l}\text { Relationship building is recognized as } \\
\text { everyone's job. }\end{array}$ & 0 & 0 & 0 & 0 & 0 \\
\hline $\begin{array}{l}\text { The trustees and president } \\
\text { communicate the college's mission of } \\
\text { labor market responsiveness in the } \\
\text { public eye and in circles of influence. }\end{array}$ & 0 & 0 & 0 & 0 & 0 \\
\hline $\begin{array}{l}\text { The college seeks out new ways to } \\
\text { market itself, regionally and nationally. }\end{array}$ & 0 & 0 & 0 & 0 & 0 \\
\hline $\begin{array}{l}\text { Marketing activities encourage others } \\
\text { to approach the college as a partner. }\end{array}$ & 0 & 0 & 0 & 0 & 0 \\
\hline $\begin{array}{l}\text { Strategic relationship building is } \\
\text { recognized as the foundation for } \\
\text { establishing strategic partnerships. }\end{array}$ & 0 & 0 & 0 & 0 & 0 \\
\hline \multirow[t]{3}{*}{$\begin{array}{l}\text { Strategic relationship building is } \\
\text { recognized as the foundation for } \\
\text { establishing strategic partnerships. }\end{array}$} & 0 & 0 & 0 & 0 & 0 \\
\hline & & & & & \\
\hline & Not at all & Slightly & Somewhat & $\begin{array}{l}\text { Almost } \\
\text { always }\end{array}$ & Completely \\
\hline $\begin{array}{l}\text { The college is engaged in sustained, } \\
\text { successful employer partnerships that } \\
\text { are responsive to the local market. }\end{array}$ & 0 & 0 & 0 & 0 & 0 \\
\hline $\begin{array}{l}\text { The college has established strategic } \\
\text { priorities for partnership building with } \\
\text { employers, aligned with the } \\
\text { community's needs. }\end{array}$ & 0 & 0 & 0 & 0 & 0 \\
\hline $\begin{array}{l}\text { The partnerships in which your college } \\
\text { takes part anticipate local economic } \\
\text { development and growth. }\end{array}$ & 0 & 0 & 0 & 0 & 0 \\
\hline $\begin{array}{l}\text { The college has identified and } \\
\text { partnered with the right mix of } \\
\text { organizations. }\end{array}$ & 0 & 0 & 0 & 0 & 0 \\
\hline $\begin{array}{l}\text { The college partners with large } \\
\text { employers and innovative industries. }\end{array}$ & 0 & 0 & 0 & 0 & 0 \\
\hline $\begin{array}{l}\text { The college encourages and rewards } \\
\text { its staff for entrepreneurial activity. }\end{array}$ & 0 & 0 & 0 & 0 & 0 \\
\hline $\begin{array}{l}\text { Partnerships are assessed and } \\
\text { maintained in proportion to the ability } \\
\text { to leverage long-term outcomes and } \\
\text { opportunities. }\end{array}$ & 0 & 0 & 0 & 0 & 0 \\
\hline
\end{tabular}


Demographics

How long have you served as

President and/or CEO of your current

community and technical college?

What are your total years of

experience as an administrator in a

community and technical college?

If you have experience other than highe

education administration, please describe

your experience.

What year was your community and

technical college established?

Is your community and technical

college administratively linked to

another institution?

If yes, which institution?

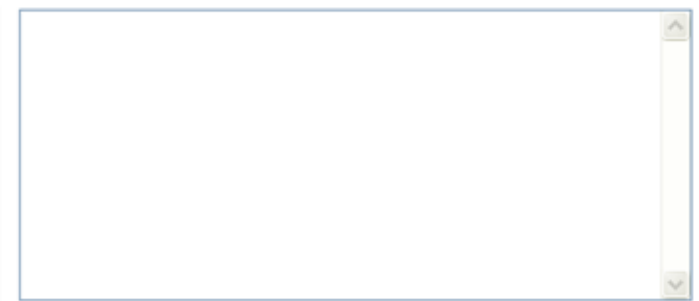

What is your highest degree earned?

\section{$\square$ MA \\ $\square$ MBA \\ $\square$ MS \\ $\square$ MD \\ $\square$ EdD \\ $\square \mathrm{JD}$ \\ $\square \mathrm{PhD}$ \\ $\square$ other}

If 'Other' please specify.

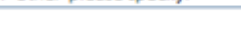

In what field is your highest degree?

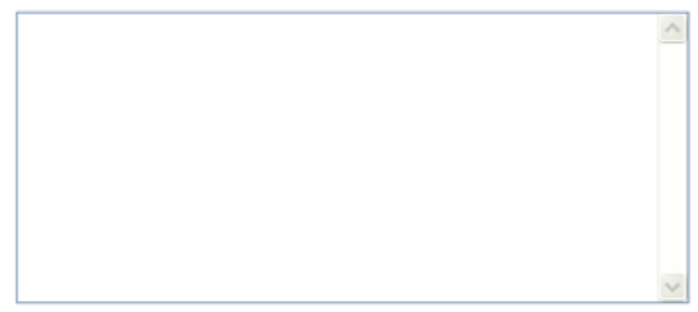

What is your age?

$\square 35$ or under

$\square 36-45$

$\square 46 \cdot 55$

$\square 56 \cdot 65$

$\square 66$ and over

What is your gender?

$\square$ Male

$\square$ Female

Submit This Form 


\section{APPENDIX C}

Letter to Presidents

Date

Community and Technical College

Street address

City, WV zip code

Dear President,

This letter is a request for your participation in research as part of my doctoral

dissertation. The purpose of my research is to determine to what extent the Presidents of the ten public West Virginia community and technical colleges perceive their institutions as able to implement seven dimensions of college life in support of labor market responsiveness. Labor market responsiveness can be described as the ability to deliver programs and services that align with the changing dynamics of the labor market served by a community college.

I'm requesting that you take approximately 12 to 15 minutes to complete a survey. The survey is found at http://simpleforms.scripts.wvu.edu/sf/LaborMarket. I will send you an e-mail containing this link which may be more convenient for you to access.

The survey is adapted with permission from the U.S. Department of Education, Office of Vocational and Adult Education, "The $21^{\text {st }}$-Century Community College: A Strategic Guide to Maximizing Labor Market Responsiveness."

Your participation in this survey is completely voluntary and you have the right to not respond to every item. Your confidentiality will be maintained in this research. This project has been reviewed by West Virginia University's Institutional Research Board.

At the conclusion of my research, I would be happy to send you a copy of my findings. This study may provide you with a framework to assess your institution's position on labor market responsiveness. In addition, this particular study may be of value in future planning for your institution.

Thank you for your consideration.

Sincerely,

Ann Shipway

Doctoral Student 


\section{APPENDIX D}

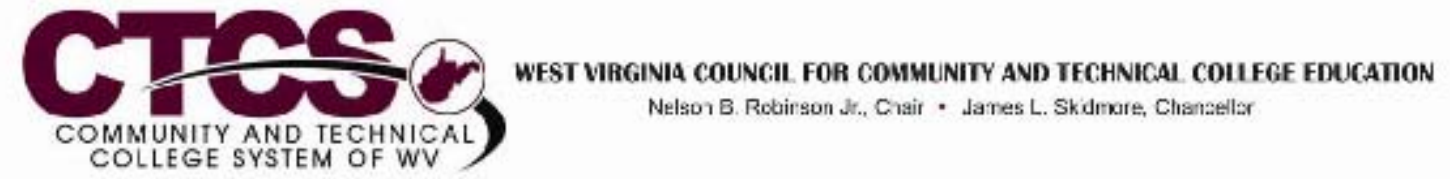

May 23, 2007

Dear Doctoral Committee,

Over the past decade, the state of West Virginia has been developing a comprehensive system of community and technical colleges. A key feature of any community and technical college is an active and vibrant workforce development program. The research undertaken by Ann Shipway in her proposed dissertation will provide much needed empirically based information that can be used to further develop our community and technical college system.

I am very appreciative of the work that Ann is doing and it has my endorsement. Ann Shipway has my permission to contact the community and technical college Presidents to gather the data requested in support of her dissertation.

\section{Sincerely,}

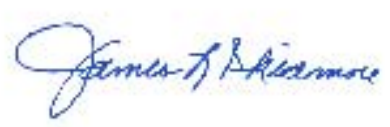

James L. Skidmore

Chancellor 